\title{
MÉTODO DE SELEÇÃO EM MILHO PARA RESISTÊNCIA AO VÍRUS DA RISCA - FITOPLASMA - ESPIROPLASMA
}

\author{
ROSELI TERESINHA PAES BARBOSA BORGES \\ Engenheiro Agrônomo
}

Orientador: Prof. Dr. João Rubens Zinsly

\begin{abstract}
Tese apresentada à Escola Superior de Agricultura "Luiz de Queiroz", Universidade de São Paulo, para a obtenção do título de Doutor em Agronomia, Área de Concentração: Genética e Melhoramento de Plantas.
\end{abstract}

\author{
PIRACICABA \\ Estado de São Paulo - Brasil \\ Novembro - 1997
}


Dados Internacionais de Catalogação na Publicação (CIP) DIVISĀO DE BIBLIOTECA E DOCUMENTAÇĀO - Campus "Luiz de Queiroz"/USP

Borses, Renell Terentinta Paes Barbosa

Método de seleção em milho para resistêncla ao virus da risca - fitoplasma espiroplasma / Rosell Teresinha Paes Barbosa Borges, - Piracicaba, 1997.

58 p. : il.

Tese (doutorado) - Escola Superior de Agricultura Luiz de Queiroz, 1998. Bibliografia.

1. Micoplasma de planta 2. Milho 3. Melhoramento genético 4. Resistência a doença 5 . Seleção genética vegetal 6 . Virus de planta 1. Titulo 


\section{MÉTODO DE SELEÇÃO EM MILHO PARA RESISTÊNCIA AO VÍRUS DA RISCA - FITOPLASMA - ESPIROPLASMA}

ROSELI TERESINHA PAES BARBOSA BORGES

Aprovada em: 28.01.1998

Comissão julgadora:

Prof. Dr. João Rubens Zinsly

ESALQ/USP

Prof. Dr. Eric Balmer

ESALQ/USP

Prof. Dr. Antonio Ismael Bassinello

Universidade de São Carlos

Prof. Dr. José Roberto Môro

UNESP - Campus de Jaboticabal

Prof. Dr. Juan Ayala Osuna

UNESP - Campus de Jaboticabal

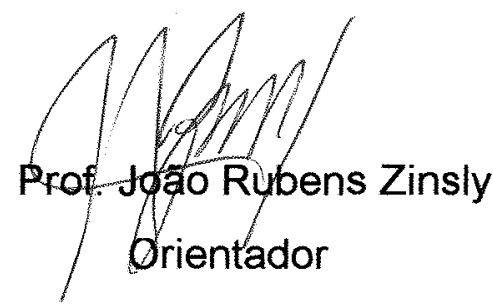


$i$

Dedica

200

meus

familiares 


\section{AGRADECIMENTOS}

Sinceros agradecimentos as pessoas e instituições que direta ou indiretamente contribuiram para o desenvolvimento deste trabalho de tese, em especial:

- Prof. Dr. João Rubens Zinsly;

- Prof. Dr. Eric Balmer;

- Professores do curso de pós-graduação em Genética e Melhoramento de Plantas;

- Funcionários do Setor de Milho do Departamento de Genética;

- Colegas do curso de pós-graduação;

- Funcionários das bibliotecas do Campus e das Secretarias de pósgraduação;

- CNPq. 


\section{SUMÁRIO}

Página

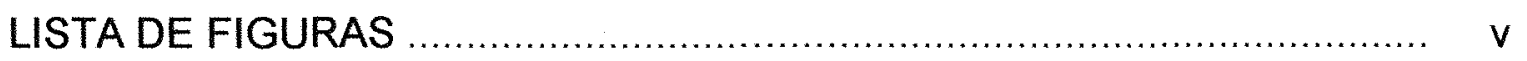

LISTA DE TABELAS ............................................................... vii

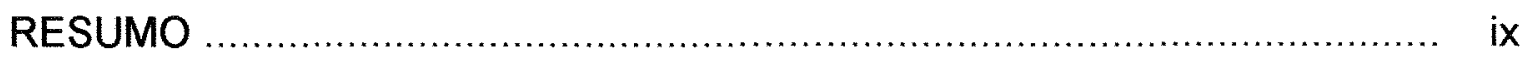

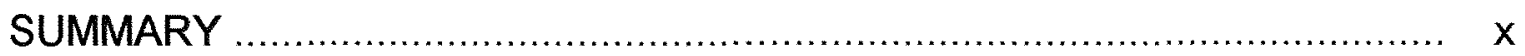

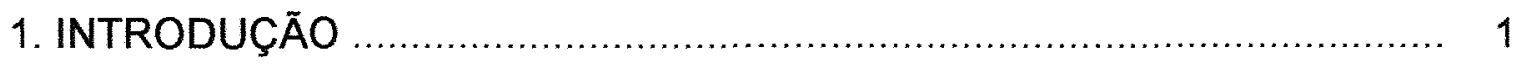

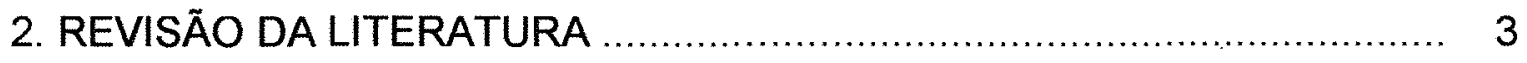

2.1 Descrição da doença .................................................................. 3

2.2 Deteç̧ão e identificação dos agentes causais .................................. 5

2.3 Quadro sintomatológico .......................................................... 6

2.4 Agentes transmissores do "complexo" formado por fitoplasma,

espiroplasma $e$ viroses ......................................................... 8

2.5 Interação entre os agentes causais do "enfezamento" do milho ............ 10

2.6 Controle químico da cigarrinha Dalbulus maidis .................................. 11

2.7 Efeitos genéticos e herança da resistência ..................................... 12

2.8 Avaliação e seleção de cultivares ................................................... 12

3. MATERIAIS E MÉTODOS ............................................................ 15

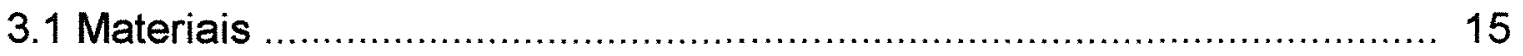

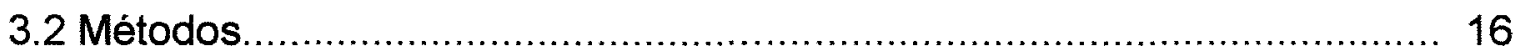

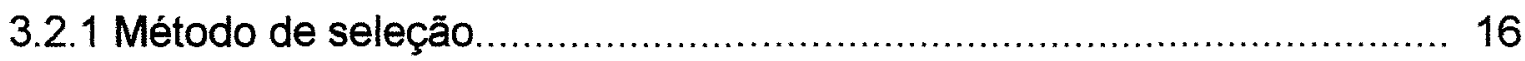

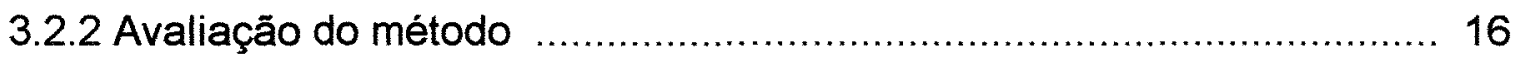

3.2.3 Eficiência do método ......................................................... 17

3.2.4 Obtenção dos dados de severidade de infecção .............................. 18

3.2.5 Respostas correlacionadas ...................................................... 25

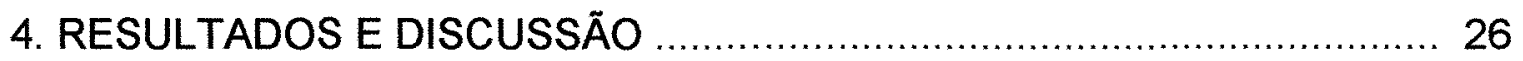

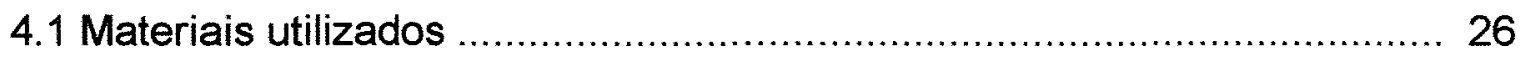

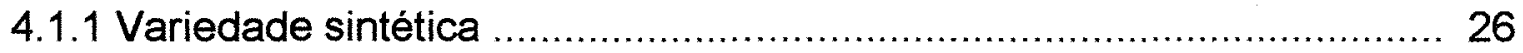




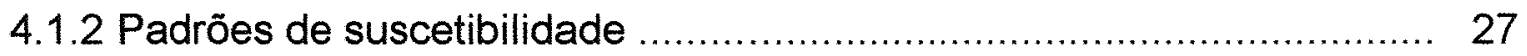

4.1.3 Híbrido comercial ............................................................ 27

4.2 Fases do método de seleção ..................................................... 28

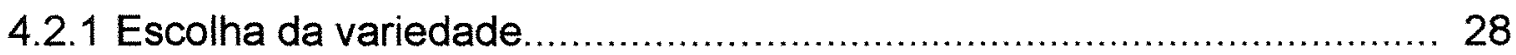

4.2.2 Obtenção das progênies de meios irmãos .................................... 28

4.2.3 Uso de testemunha intercalar .................................................... 29

4.2.4 Escolha do ambiente de seleção ................................................... 29

4.2.5 Aumento da endogamia dos genótipos selecionados ...................... 31

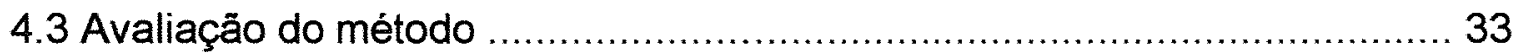

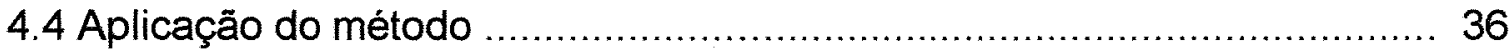

4.4.1 Severidade de infecção ............................................................. 36

4.4.2 Respostas correlacionadas ................................................. 43

4.5 Considerações gerais ............................................................ 46

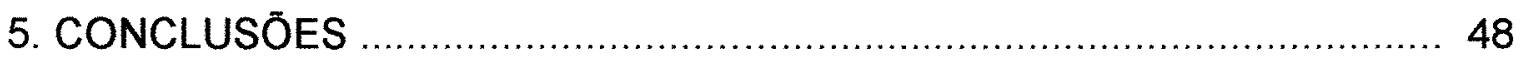

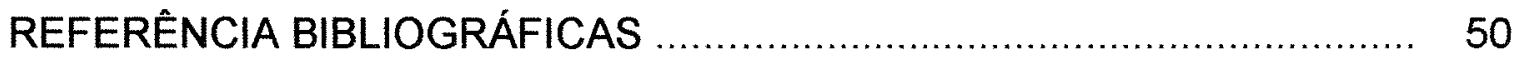


1 Plantas sem sintomas aparentes de infecção na parte superior - classe 0

2 Plantas com bom desenvolvimento vegetativo, mas com avermelhamento das folhas superiores - classe 0,5

3 Planta apresentando leve redução no desenvolvimento dos últimos internódios, e emissão incompleta do pendão classe 1

4 Planta apresentando encurtamento acentuado dos internódios superiores - classe 2

5 Planta apresentando redução drástica no desenvolvimento devido ao encurtamento dos internódios do terço superior - classe 3

6 Planta apresentando sintomas característicos do "complexo", com enfezamento severo e redução dos internódios médios e superiores - classe 4

7 Uniformidade de infecção apresentada pela progênies PS 135.1.1 à direita, comparada ao tratamento correspondente ao terceiro ciclo de seleção à esquerda 
Página

8 Médias obtidas para Níveis Totais de Resistência (NTR), nos quatro experimentos conduzidos na Estação Experimental de Anhembi, Piracicaba, SP, em 95/96

9 Médias obtidas para porcentagem de plantas sem sintomas evidentes de enfezamento, nos quatro experimentos conduzidos na Estação Experimental de anhembi, Piracicaba, SP, em 95/96

10 Médias obtidas para peso de grãos, nos quatro experimentos conduzidos na Estação Experimental de Anhembi, Piracicaba, SP, em 95/96 


\section{LISTA DE TABELAS}

Página

1 Descrição da escala diagramática desenvolvida por BALMER et al. (1990)

2 Análise conjunta de variância da caractarística: Níveis Totais de Resistência (NTR)

3 Análise de variânciada característica: Niveis Totais de Resistência (NTR), experimento 1

4 Análise de variância da característica: Niveis Totais de Resistência (NTR), experimento 2

5 Análise de variância da característica: Niveis Totais de Resistência (NTR), experimento 3

6 Análise de variância da característica: Níveis Totais de Resistência (NTR), experimento 4

7 Médias obtidas para níveis totais de resistência nos quatro experimentos conduzidos na Estação Experimental de Anhembi, Piracicaba, SP, em 95/96

8 Porcentagem média de plantas sem sintomas evidentes de enfezamento, nos quatro experimentos conduzidos na Estação Experimental de Anhembi, Piracicaba, SP, em 95/96 
Página

9 Valores médios observados para os componentes de produção avaliados nos quatro experimentos conduzidosna Estação Experimental de Anhembi, Piracicaba, SP, em 95/96................ 
MÉTODO DE SELEÇÃO EM MILHO PARA O "COMPLEXO" VÍRUS DA RISCAFITOPLASMA-ESPIROPLASMA

Autora: Roseli Teresinha Paes Barbosa Borges Orientador: Prof. Dr. João Rubens Zinsly

\section{RESUMO}

Duzentas e vinte progênies de meios irmãos, originárias da variedade sintética de milho "Piranão de Inverno SM XIV", constituiram o material base para o desenvolvimento de um método de seleção visando elevar a frequência de genes favoráveis à resistência ao "complexo" formado pelo vírus da riscafitoplasma-espiroplasma. Quatro ciclos de seleção foram realizados em ambiente favorável à infecção natural pelos agentes formadores do "complexo". Durante os quatro ciclos de seleção, as pressões de seleção entre e dentro das familias tiveram as seguintes magnitudes: $80,9 \%$ e $2,5 \% ; 2,0 \%$ e $3,7 \% ; 74,7$ $\%$ e $6,1 \% ; 23,9 \%$ e 4,8 \%, respectivamente, para os ciclos $\mathrm{Cl}$, CII, CIII e CIV. Após o quarto ciclo de seleção, foi avaliado o progresso genético obtido com a seleção para o "complexo" e a resposta correlacionada para componentes de produção. A metodologia em estudo revelou-se eficiente, conforme evidenciado pela avaliação feita em diferentes épocas que abrangeram desde o plantio normal até o tardio, denominado "safrinha". Os ganhos médios obtidos após o quarto ciclo de seleção foram de: a) 6,05 \% para nível total de resistência; b) $31,24 \%$ para porcentagem de plantas sem sintomas evidentes de enfezamento; e c) $10,40 \%$ para produtividade de grãos. 
MAIZE SELECTION METHOD FOR BRAZILIAN STREAK VIRUS-

PHYTOPLASM-SPIROPLASM "COMPLEX"

\author{
Author: Roseli Teresinha Paes Barbosa Borges \\ Adviser: Prof. Dr. João Rubens Zinsly
}

\title{
SUMMARY
}

Two-hundred-and-twenty half sib progenies of the corn variety "Piranão de Inverno SM XIV" were selected for agronomical characteristics and used as the basic material for genetic improvement for resistance to Brazilian streak virus, phytoplasm and spiroplasm. Four selection cycles were realized in an environment favorable to natural infection by the complex. Selection intensity for between and within families varied with environmental conditions. During the four selection cycles, selection intensity for between and within families were: $80,9 \%$ and $2,5 \% ; 2,0$ and $3,7 \% ; 74,7 \%$ and $6,1 \% ; 23,9 \%$ and $4,8 \%$ for cycles $\mathrm{Cl}, \mathrm{ClI}$, CIII and CIV, respectively. After the fourth cycle, genetic progress through selection for resistance to the complex and its correlation with production components were evaluated. Efficiency of the methodology was proven by evaluations made over the normal to late ("late planting") planting periods. Average gains obtained after the fourth selection cycle were: a) 6,05\% total resistance level; b) 31,24\% frequency of plants without symptoms; and c) $10,40 \%$ grain productivity. 


\section{INTRODUÇÃO}

O plantio consecutivo e escalonado de milho na região centro sul do país tem propiciado a existência de plantas em diferentes fases de desenvolvimento em áreas próximas durante todo o ano, o que tem contribuído para maior incidência e severidade de doenças, cujos agentes causais são prontamente multiplicados nos cultivares suscetíveis.

No caso do "complexo" formado pelo vírus da risca, fitoplasma e espiroplasma, constatamos que a maior incidência e severidade dos sintomas ocorrem durante o período da "safrinha", época correspondente à condução do segundo plantio realizado no ano agrícola. A presença de populações infectivas do inseto vetor, a cigarrinha Dalbulus maidis, associada ao plantio de cultivares de milho suscetíveis à infecção pelo "complexo" têm ocasionado perdas significativas na produtividade de grãos, nas regiões onde se realiza a "safrinha".

O controle pode ser obtido através da diminuição da densidade populacional do agente vetor, mediante a aplicação preventiva de inseticidas sistêmicos. As principais desvantagens desta medida são: a) controle parcial da população da cigarrinha; b) custo elevado para o período da "safrinha"; c) possibilidade de acarretar danos ecológicos e d) possibilidade de intoxicação do operador do produto. A utilização de cultivares de milho resistentes tem-se mostrado a medida mais eficiente.

A seleção de genótipos com maior nível de resistência deve ser feita em condições de ambiente que favoreçam a discriminação fenotípica dos 
diferentes quadros sintomatológicos resultantes da infecção pelos agentes causais do "complexo". Existe a necessidade da presença de populações infectivas da cigarrinha, para que ocorra a transmissão, em condições naturais, dos organismos patogênicos para as plantas testes.

Genótipos segregantes, locais e épocas, para a avaliação e seleção para maior nível de resistência, devem ser previamente escolhidos para a aplicação do método a ser utilizado.

Os objetivos deste trabalho foram: a) desenvolver um método de seleção em milho para elevar o nível de resistência ao "complexo" formado pelo vírus da risca, fitoplasma e espiroplasma; b) obter uma variedade resistente, adaptada ao período de plantio tardio; c) obter padrões de suscetibilidade; d) avaliar o progresso genético obtido com a aplicação do método desenvolvido; e) estimar as correlações existentes entre a característica selecionada e os componentes: peso de grãos, altura da inserção da folha bandeira e da espiga superior, prolificidade e porcentagem de espigas sadias. 


\section{REVISÃO DA LITERATURA}

\subsection{Descrição da doença}

A doença do milho denominada de enfezamento foi inicialmente observada na década de 40, nos Estados Unidos (DE LEÓN, 1984). Espalhouse naturalmente por todo o continente americano, havendo relatos de ocorrência de epidemias no início da década de 70 no Estado de Mississippi, EUA (CHOUDHURY et al., 1973) e nos anos de 1979 e 1980 na Flórida, EUA (BRADFUTE et al., 1981). No início da década de 70 também foram observados danos consideráveis em plantios tardios da região da Costa do Pacifico, na Nicarágua (MÁRQUEZ SÁNCHEZ, 1982).

NAULT \& BRADFUTE (1979) associaram o quadro sintomatológico "complexo" do enfezamento do milho a quatro agentes principais: fitoplasma, espiroplasma, vírus "chlorotic dwarf" e "rayado fino". Outros agentes também foram associados, ao quadro epidêmico observado na Flórida, por BRADFUTE et al. (1981), em especial, os vírus "rayado fino" e "dwarf mosaic (str. B)".

O vírus "chlorotic dwarf" foi o agente mais frequente nas amostras de milho analisadas por GORDON \& NAULT (1977), sendo identificado em $76 \%$ das amostras avaliadas por estes autores. Entretanto, segundo DE LEÓN (1994), este vírus está, até o presente momento, restrito aos Estados Unidos. 
O vírus "rayado fino" tem ampla distribuição geográfica na América, desde o Texas até Paysandu, no Uruguai. Parece estar restrito a este continente e assume importância crescente nas áreas tropicais (GAMEZ, 1980; GAMEZ et al., 1979; KOGEL et al., 1996 e LASTRA \& CARBALLO, 1983).

Observações histológicas revelaram que o vírus "rayado fino" assemelha-se ao virus da risca encontrado no Brasil, havendo possibilidade de ser o mesmo virus (KITAJIMA \& GAMEZ, 1977; KITAJIMA \& COSTA, 1983). Sua ocorrência é comum nos campos de milho do Brasil, principalmente nos plantios tardios (COSTA et al., 1971; KITAJIMA \& COSTA, 1983), sendo considerado o principal vírus associado aos agentes do enfezamento nas regiões do país onde se cultiva a "safrinha".

A diminuição na produtividade devido à incidência deste "complexo" é variável de acordo com as características da população do inseto vetor, do germoplasma e das condições ambientais. KITAJIMA \& COSTA (1972) associaram, ainda, as perdas na produtividade ao movimento da cigarrinha para as áreas de cultivo de milho neste período.

SCOTT \& ROSENKRAZ (1977) avaliaram as perdas resultantes da infecção pelos agentes do enfezamento, vírus "chlorotic dwarf" e fitoplasma, sob condições de campo durante cinco anos consecutivos. Os híbridos de milho avaliados foram naturalmente infectados, $e$, a produtividade das plantas com sintomas foi comparada com a produtividade das plantas que não exibiam sintomas. Os resultados indicaram que as plantas que exibiam sintomas antes de 52 dias após a semeadura não produziam grãos, enquanto que aquelas que exibiam sintomas com 107 dias após a semeadura produziam normalmente. Dentro deste intervalo as perdas aumentavam progressivamente e a produtividade diminuia linearmente obedecendo $1,82 \times \mathrm{n} \%$, onde $\mathrm{n}$ era 0 número de dias antes do limite superior para o aparecimento dos sintomas. 0 número de espigas e de grãos por planta tiveram maior redução que o peso de grãos. 
NELSON \& SCOTT (1973) estimaram correlações negativas entre severidade de infecção e produção de grãos na ordem de $-0,74^{*},-0,80^{* *}$ e $-0,77^{\star *}$. Estes valores foram obtidos em três experimentos conduzidos para avaliar híbridos simples originários de um cruzamento dialélico entre linhagens classificadas como suscetíveis, intermediárias e resistentes.

\subsection{Detecção e identificação dos agentes causais}

O diagnóstico de fitoplasma associado ao quadro sintomatológico resultante da infecção requer a observação deste agente no floema das plantas através de microscopia eletrônica ou a análise sorológica ou de DNA deste patógeno nas plantas e nos insetos transmissores (HARRISON et al., 1996).

A associação entre espiroplasma e enfezamento foi inicialmente realizada por DAVIS et al. (1973), através da distinção deste microrganismo das espécies descritas de micoplasmas pela análise de microscopia eletrônica e de contraste de fase. Estes autores observaram que esses organismos assumiam a forma helicoidal e exibiam movimentos semelhantes a alguns espiroquetas, razão pela qual foi sugerido, nesta ocasião, o nome trivial de espiroplasmas. Uma prova desta associação foi obtida por DAVIS (1974) pela observação deste agente no inseto vetor e através da coincidência no período de incubação do agente transmissor do enfezamento na cigarrinha Dalbulus maidis com o de espiroplasma. Outra indicação foi relatada por DAVIS (1973) relacionada com a observação, por microscopia de contraste de fase, de espiroplasma em lâminas preparadas a partir de plantas de milho naturalmente infectadas e que exibiam sintomas típicos da infecção pela estirpe "Rio Grande" e "Mesa Central". Esta técnica de identificação também foi utilizada por OVERMAN et al. (1992). 
CHEN \& LIAO (1975) constataram a patogenicidade do espiroplasma através do isolamento deste agente de plantas infectadas, consequente cultivo in vitro e reprodução dos sintomas em plantas testes colocadas previamente em contato com o inseto vetor infectado pela cultura pura obtida. Espiroplasma foi reisolado das plantas inoculadas e foi morfologicamente idêntico ao isolado original.

Métodos sorológicos tem sido utilizados para identificar espiroplasma em plantas doentes e nos insetos vetores, através de uma reação entre $\mathrm{o}$ antisoro e antígeno com coloração forte sem efeito detrimental (EDENGREEN, 1982; NOME et al., 1981 e RAJU \& NYLUND, 1981).

A técnica de amplificação do DNA por PCR (polymerase chain reaction) também tem sido utilizada para detectar os agentes associados ao enfezamento do milho. Estudos tem sido realizados no sentido de aplicar esta técnica na detecção destes agentes nos insetos vetores (HARRISON et al., 1996).

\subsection{Quadro sintomatológico}

Os sintomas típicos causados por espiroplasma nas plantas infectadas são manchas cloróticas e estrias na base das folhas mais jovens, redução dos entrenós, desenvolvimento de espigas estéreis nas gemas axilares e ramificação excessiva de raízes (DE LEÓN, 1994; NAULT, 1980 e NOME et al., 1981).

NAULT (1980) observou as manchas cloróticas e estrias nas folhas somente em condições de temperaturas elevadas. Sob condições de baixas temperaturas os sintomas produzidos assemelhavam-se aos causados por fitoplasma.

O agente fitoplasma causa enfezamento mais severo e maior proliferação de gemas axilares e basais em relação ao quadro sintomatológico 
causado por espiroplasma (NAULT, 1980). As plantas infectadas apresentam clorose nas folhas jovens e avermelhamento das extremidades destas a medida que amadurecem. Os perfilhos basais também apresentam este avermelhamento e as gemas axilares, que se desenvolvem, formam espigas estéreis (DE LEÓN, 1994). No Brasil, a formação de perfilhos basais, decorrente da infecção por fitoplasma, não é frequente, conforme citação de KITAJIMA \& COSTA, 1983.

Os sintomas característicos do vírus "rayado fino" são estrias cloróticas finas paralelas às nervuras das folhas (GAMEZ, 1980). Estas estrias são resultantes da fusão de numerosas manchas cloróticas que avançam no sentido da nervura (DE LEÓN, 1994).

As plantas atacadas pelo vírus "chlorotic dwarf" apresentam encurtamento dos entrenós, espigas de pequeno tamanho e mal formadas. As folhas mostram manchas cloróticas, que se fundem formando manchas largas ao longo das nervuras (DE LEÓN, 1994).

Apesar destas distinções, sintomatologia complexa é conferida por infecções mistas e variações nos sintomas podem aparecer devido aos efeitos do genótipo hospedeiro, estirpe do patógeno e condições ambientais (BRADFUTE et al., 1981; DAVIS, 1984; GORDON \& NAULT, 1977 e HARRISON et al., 1996). A identificação de espiroplasma em plantas naturalmente infectadas, que exibiam os sintomas das raças "Rio Grande" e "Mesa Central", realizada por DAVIS (1973), confirma a complexidade das interações existentes para a manifestação dos sintomas, que podem assumir diferentes formas. 
2.4 Agentes transmissores do "complexo" formado por fitoplasma, espiroplasma e viroses

Diferentes espécies de cigarrinhas foram associadas à transmissão deste "complexo" de patógenos: Dalbulus maidis (DeLong \& Wolcott), Dalbulus elimatus (Ball.), Graminella nigrifrons (Forbes), Deltocephasus sonorus (Ball.) e Baldulus tripsaci (Kramer \& Whitcomb) (SCOTT \& ROSENKRAZ, 1977). NAULT (1980) observou a transmissão de espiroplasma e de fitoplasma pelas espécies Dalbulus maidis, Dalbulus elimatus e Graminella nigrifrons. Espiroplasma também foi transmitido por Exitianus exitiosus e Stirellus bicolor.

GRANADOS \& WHITCOMB (1971) observaram que, em condições de laboratório, ninfas da cigarrinha Baldulus tripsaci eram capazes de transmitir fitoplasma de planta para planta de milho. Entretanto, este agente só foi observado, em condições de campo, em plantas da espécie Tripsacum dactyloides, sendo considerado um vetor eventual de fitoplasma. Como as plantas de Tripsacum dactiloides são também fonte de alimentos para Dalbulus maidis, um importante vetor de fitoplasma, os autores consideraram que Tripsacum dactiloides poderia ser considerado como um hospedeiro.

Euchlaena mexicana, Zea perennis e Zea diploperennis também foram considerados hospedeiros dos agentes do enfezamento por NAULT (1980). A presença dos agentes causais do enfezamento nos ancestrais do milho levantaram a possibilidade de que estes patógenos teriam interferido no processo de especiação e distribuição deste e de seus ancestrais (NAULT \& BRADFUTE, 1979).

BLASINGAME \& TOLER (1973) observaram espiroplasma no tecido maturo do floema de plantas infectadas de Sorghum halepense e de milho. A cigarrinha Graminella nigrifrons transmitiu a doença de plantas 
infectadas de Sorghum halepense para plantas indicadoras de milho, porém Dalbulus maidis não efetuou esta transmissão.

Graminella nigrifrons foi um agente transmissor eficiente do vírus "chlorotic dwarf" observado em Ohio (CHOUDHURY \& ROSENKRAZ, 1973). Estes autores relataram que esta cigarrinha também adquiria fitoplasma de plantas inoculadas por Dalbulus maidis e de plantas de milho naturalmente infectadas no campo.

Em estudo realizado por PANIAGUA \& GAMEZ (1976), foram observadas diferenças na transmissão do vírus "rayado fino" de acordo com o sexo da cigarrinha Dalbulus maidis, assim como eficiência na seleção realizada na população de cigarrinhas para maior capacidade de infecção. LEGRAND \& POWER (1994) não observaram diferença significativa entre sexos na transmissão de fitoplasma por esta cigarrinha.

WOLANSKI \& MARAMOROSCH (1979) confirmaram a transmissão do vírus "rayado fino" pela cigarrinha Dalbulus maidis e estabeleceram a transmissão por Dalbulus elimatus. A cigarrinha Dalbulus elimatus é um vetor importante de espiroplasma, porém CHEN \& LIAO (1975) observaram que este agente é patogênico para a mesma.

GAMEZ (1973) observou a transmissão simultânea de espiroplasma e do vírus "rayado fino" pela cigarrinha Dalbulus maidis. Este autor relatou que, com o tempo, os insetos perdiam a capacidade de transmissão, mas mantinham o vírus mesmo depois de terem perdido o poder de transmití-lo.

No Brasil, existe, somente, o relato da existência da cigarrinha Dalbulus maidis como agente transmissor do enfezamento pálido, vermelho e vírus da risca (KITAJIMA \& COSTA, 1972; KITAJIMA \& COSTA, 1983).

De acordo com NAULT (1984b) esta cigarrinha representa o principal agente vetor, estando presente em todos os locais da América, onde ocorre enfezamento do milho. Além da ampla distribuição geográfica, 
envolvendo Estados Unidos, México, América Central e América do Sul, a cigarrinha Dalbulus maidis é altamente especializada em milho caracterizando o potencial desta como uma praga para a cultura (NAULT, 1984b).

\subsection{Interação entre os agentes causais do "enfezamento" do milho}

Os agentes causais do "enfezamento" podem estar presentes em uma mesma planta, conforme demonstração feita por WOLANSKI \& MARAMOROSCH (1979). Estes autores inocularam plantas de milho com o vírus "rayado fino" e espiroplasma e observaram estes agentes restritos ao floema das plantas inoculadas. Embora desenvolvendo-se nas mesmas plantas nunca foram observados, por estes autores, na mesma célula.

CHOUDHURY \& ROSENKRAZ (1973) demonstraram que cigarrinhas da espécie Graminella nigrifrons poderiam ser infectadas por fitoplasma e pelo vírus "chlorotic dwarf" provenientes de uma mesma planta. Estes autores observaram que nas colônias de G. nigrifrons existiam indivíduos que transmitiam somente "chlorotic dwarf", somente espiroplasma ou ambos para a mesma planta teste. Quando as plantas recebiam os dois agentes desenvolviam primeiramente sintomas da infecção causada pelo vírus e depois pelo espiroplasma. Quando as cigarrinhas eram expostas a estas plantas testes ocorria a formação de subcolônias que transmitiam os agentes individualmente ou em conjunto, sendo mais frequente o desenvolvimento de subcolônias que transmitiam somente o vírus devido à maior eficiência desta cigarrinha na transmissão deste. 


\subsection{Controle químico da cigarrinha Dalbulus maidis}

O controle químico da cigarrinha Dalbulus maidis como forma de diminuir a incidência do enfezamento em plantas de milho foi avaliado por BHRIRUD \& PITRE (1972a), BHRIRUD \& PITRE (1972b) e WAQUIL \& CRUZ (1994).

BHRIRUD PITRE (1972a) avaliaram a eficiência dos inseticidas carbofuran, aldicarb, metomyl, propoxur, phorate, dissulfoton e fenthion para o controle da cigarrinha Dalbulus maidis em condições de campo. Estes inseticidas sistêmicos foram aplicados na forma granular no sulco de plantio. A porcentagem de plantas infectadas variou de acordo com o tratamento, sendo de 16, 62 e $78 \%$ com os inseticidas carbofuran, aldicarb e metomyl, respectivamente. Os demais tratamentos, incluindo parcelas não tratadas, apresentaram valores na ordem de 94 à $97 \%$. Em condições de casa de vegetação, estes autores demonstraram que a eficiência dos inseticidas aldicarb e carbofuran estava associada à concentração do produto aplicado durante o período da semeadura e ao período em que era permitido ao inseto alimentar-se da planta tratada. BHIRUD \& PITRE (1972b) demonstraram que ninfas no terceiro ínstar eram mais sensíveis aos inseticidas, carbofuran e dissulfoton, que ninfas no quinto ínstar e adultos.

WAQUIL \& CRUZ (1994) avaliaram a aplicação de inseticidas sistêmicos durante o processo de tratamento das sementes. Entretanto, estes autores não observaram diferenças na densidade populacional de indivíduos adultos, durante a fase de desenvolvimento da cultura no campo. 


\subsection{Efeitos genéticos e herança da resistência}

Estudos revelaram que efeitos genéticos aditivos são predominantes para a característica de resistência ao enfezamento (GROGAN \& ROSENKRAZ, 1968; NELSON \& SCOTT, 1973), sendo que a herança da resistência é de natureza quantitativa (MÁRQUEZ SÁNCHEZ, 1982).

As localizações dos diferentes genes que condicionam a resistência foram associadas ao braço curto dos cromossomos 1 e 4 e ao braço longo dos cromossomos 3,6 e 9 (MIRANDA et al., 1983 e SCOTT \& ROSENKRAZ, 1977b).

SCOTT \& ROSENKRAZ (1977b) afirmaram que, embora, os genes que condicionavam a resistência ao "complexo" estivessem localizados nos mesmos braços cromossômicos, diferentes sistemas genéticos controlavam a reação da planta a cada agente causal.

\subsection{Avaliação e seleção de cultivares}

As reações dos cultivares em condições de campo têm sido avaliadas através do uso de escalas diagramáticas, elaboradas de acordo com a frequência de plantas infectadas nas parcelas e/ou com a severidade do quadro sintomatológico evidenciado pelas plantas (SCOTT \& ROSENKRAZ, 1975; NELSON \& SCOTT, 1973 e BALMER et al., 1990).

Os métodos desenvolvidos para a seleção tiveram por base a ação gênica aditiva para a reação de resistência das plantas ao enfezamento. SCOTT \& ROSENKRAZ (1974b) desenvolveram três métodos de seleção recorrente, obtendo o melhor progresso de seleção na população $\mathrm{Cl}$ originária da recombinação de progênies $\mathrm{S} 1$ selecionadas de acordo com o desempenho destas nos ensaios de avaliação. 
A avaliação de progênies $\mathrm{S} 1$ ou de irmãos germanos para a obtenção de populações melhoradas, também, foi considerada no programa de incorporação de resistência múltipla desenvolvido pelo CIMMYT (CENTRO INTERNACIONAL DE MEJORAMENTO DE MILHO Y TRIGO, com sede na cidade do México). Este programa consistiu na obtenção das progênies de irmãos germanos ou autofecundadas das populações e posterior avaliação destas em seis localidades da África, América Central e Sudeste Asiático. Com base nos resultados, as progênies foram recombinadas para reconstituir as populações, as quais foram utilizadas para a obtenção de novas progênies destinadas ao ciclo seguinte (RENFRO, 1977). Segundo DE LEÓN (1982), este programa resultou em três variedades resistentes.

MÁRQUEZ SÁNCHEZ (1982) desenvolveu um projeto científico, como atividade de professor visitante na Faculdade de Ciências Agrárias da Universidade Nacional Autônoma da Nicarágua. Utilizou duas variedades de milho: uma resistente ao enfezamento e outra ao "downy mildew". Ao cruzar as duas populações, considerou a obtenção de progênies com genes de resistência às duas enfermidades, com as quais, após o equilíbrio de ligamento, seria realizado o estudo das ações gênicas, mediante a aplicação do Desenho Genético I, da Carolina do Norte, para cada enfermidade, e, a obtenção de variedades e/ou híbridos resistentes às duas doenças do milho.

BREWBAKER et al. (1991) avaliaram o comportamento de linhagens endogâmicas tropicais de milho com alta capacidade geral de combinação diante da infecção por sete viroses e fitoplasma, sendo a resistência derivada, primariamente, das regiões onde cada agente era, originalmente, endêmico. A resistência ao enfezamento foi observada em $23 \%$ das linhagens.

SCOTT \& ROSENKRAZ (1975) consideraram a introdução de germoplasmas exóticos como forma para a obtenção de fonte de resistência ao 
enfezamento do milho, enquanto que NAULT \& FINDLEY (1981) consideraram a utilização de cruzamentos interespecíficos.

No Brasil, têm sido relatadas informações, referentes ao enfezamento, obtidas nos ensaios de avaliação de genótipos conduzidos em diferentes ambientes (DUARTE et al., 1994a e DUARTE et al., 1994b). 


\section{MATERIAIS E MÉTODOS}

\subsection{Materiais}

Para a realização deste trabalho foram utilizados os seguintes materiais:

a) variedade sintética de milho "Piranão de Inverno SM XIV";

Principais características:

- variedade braquitica, devido aos efeitos do gene br-2;

- gräos amarelos e dentados;

- ciclo normal;

- variabilidade genética às infecções causadas pelos agentes do enfezamento e vírus da risca;

- adaptação ao periodo de plantio tardio.

b) padröes de suscetibilidade;

Principais caracteristicas:

- apresentar fixada a reação de suscetibilidade das plantas às infecçōes causadas pelos agentes causais do enfezamento e vírus da risca. 
c) $\geq 8392$

Principais características:

- hibrido desenvolvido pela Zêneca Sementes Ltda;

- hibrido simples, superprecoce;

- grãos de coloração laranja, do tipo semiduro;

\subsection{Métodos}

\subsubsection{Método de seleção}

O método em estudo tem por base as seguintes fases:

a) escolha da variedade;

b) obtenção das progênies de meios irmãos;

c) uso de testemunha intercalar;

d) escolha do ambiente;

e) aumento da endogamia dos genótipos selecionados.

\subsubsection{Avaliação do método}

Este método foi aplicado na seleção em milho dirigida para elevar o nível de resistência ao "complexo" formado pelo vírus da risca, fitoplasma e espiroplasma.

Duzentas e vinte progênies de meios irmãos, originárias da variedade sintética "Piranão de Inverno SM XIV" foram avaliadas em duas repetiçōes, sendo uma conduzida na área experimental do Departamento de Genética, ESALQ/USP, situada em Piracicaba, SP, local de desenvolvimento 
da variedade sintética, e outra na Estação Experimental de Anhembi, situada na divisa dos municipios de Piracicaba e Anhembi, SP.

As parcelas foram constituídas por cinquenta plantas, sendo intercalada a cada três fileiras de progênies uma fileira da variedade "Piranão de Inverno SM XIII". A infecção das plantas pelos agentes causais do enfezamento e vírus da risca foi efetuada em condiçōes naturais.

Após a instalação das repetiçōes, foram realizadas visitas frequentes às áreas experimentais em estudo, sendo selecionada, durante a fase de desenvolvimento das plantas, a Estação Experimental de Anhembi para a condução do trabalho. Foram feitas dez polinizaçōes entre as plantas com menor nivel de enfezamento dentro de cada progênie. Após esta atividade, foram identificadas as melhores plantas polinizadas, tendo por base a evolução do quadro sintomatológico, associado à infecção pelo "complexo" formado pelo vírus da risca, fitoplasma e espiroplasma, em relação às plantas da população original.

As espigas originárias das plantas selecionadas foram mantidas individualizadas e destinadas ao ciclo seguinte de seleção. Três novos ciclos de seleção foram realizados, na Estação Experimental de Anhembi, mantendo-se a população original como referência entre as fileiras das progênies. As pressões de seleção, entre e dentro das fileiras, não foram fixadas.

No decorrer do trabalho de seleção, amostras de plantas infectadas foram encaminhadas para análise laboratorial, a fim de identificar quais os agentes causais associados aos sintomas observados.

\subsubsection{Eficiência do método}

A eficiência do método foi demonstrada através da avaliação do progresso genético obtido com a sua aplicação. Foram instalados quatro 
experimentos, na Estaçäo Experimental de Anhembi, SP, com as seguintes datas de plantio: 29/11/95, 10/1/96, 8/2/96 e 14/3/96.

$O$ delineamento experimental utilizado foi o de Blocos ao Acaso, com parcelas de dez metros de comprimento e dez repetições. Os tratamentos foram representados pela variedade sintětica "Piranão de Inverno SM XIII", "Piranäo de Inverno SM XIV", os diferentes ciclos de seleção, três padröes de suscetibilidade e o híbrido comercial, Z 8392.

\subsubsection{Obtenção dos dados de severidade de infecção}

Foi aplicada a escala diagramática desenvolvida por BALMER et al. (1990), conforme descrição feita na Tabela 1.

Tabela 1: Descrição da escala diagramática desenvolvida por BALMER et al. (1990).

\begin{tabular}{c|l}
\hline Classes & \multicolumn{1}{c}{ Graus de Severidade da Infecção } \\
\hline 0 & $\begin{array}{l}\text { Plantas sem sintomas aparentes, (Figura 1). } \\
\text { Plantas não apresentando sintomas de encurtamento de } \\
\text { internódios, mas com avermelhamento das últimas superiores, } \\
\text { (Figura 2). }\end{array}$ \\
$\begin{array}{l}\text { Plantas apresentando leve redução no desenvolvimento dos últimos } \\
\text { internódios, apresentando encurtamento no segmento basal do } \\
\text { pendão ou não emissão deste, (Figura 3). } \\
\text { Redução no desenvolvimento da parte aérea da planta, evidenciado } \\
\text { pelo encurtamento dos últimos internódios formados na planta, } \\
\text { (Figura 4). }\end{array}$ & $\begin{array}{l}\text { Redução considerável no desenvolvimento da parte aérea da planta } \\
\text { resultante do encurtamento dos internódios do terço superior, } \\
\text { podendo as folhas apresentarem sintomas de amarelecimento, } \\
\text { avermelhamento ou necrose, (Figura 5). } \\
\text { Enfezamento severo da planta resultante do encurtamento de um } \\
\text { considerável número de internódios do terço superior e médio da } \\
\text { planta, podendo as plantas apresentarem considerável clorose elou } \\
\text { avermelhamento, e necrose, sintomatologia complexa, (Figura 6) }\end{array}$ \\
\hline
\end{tabular}


Foram consideradas as vinte e cinco primeiras plantas das parcelas e, posteriormente, calculada a média por parcela.

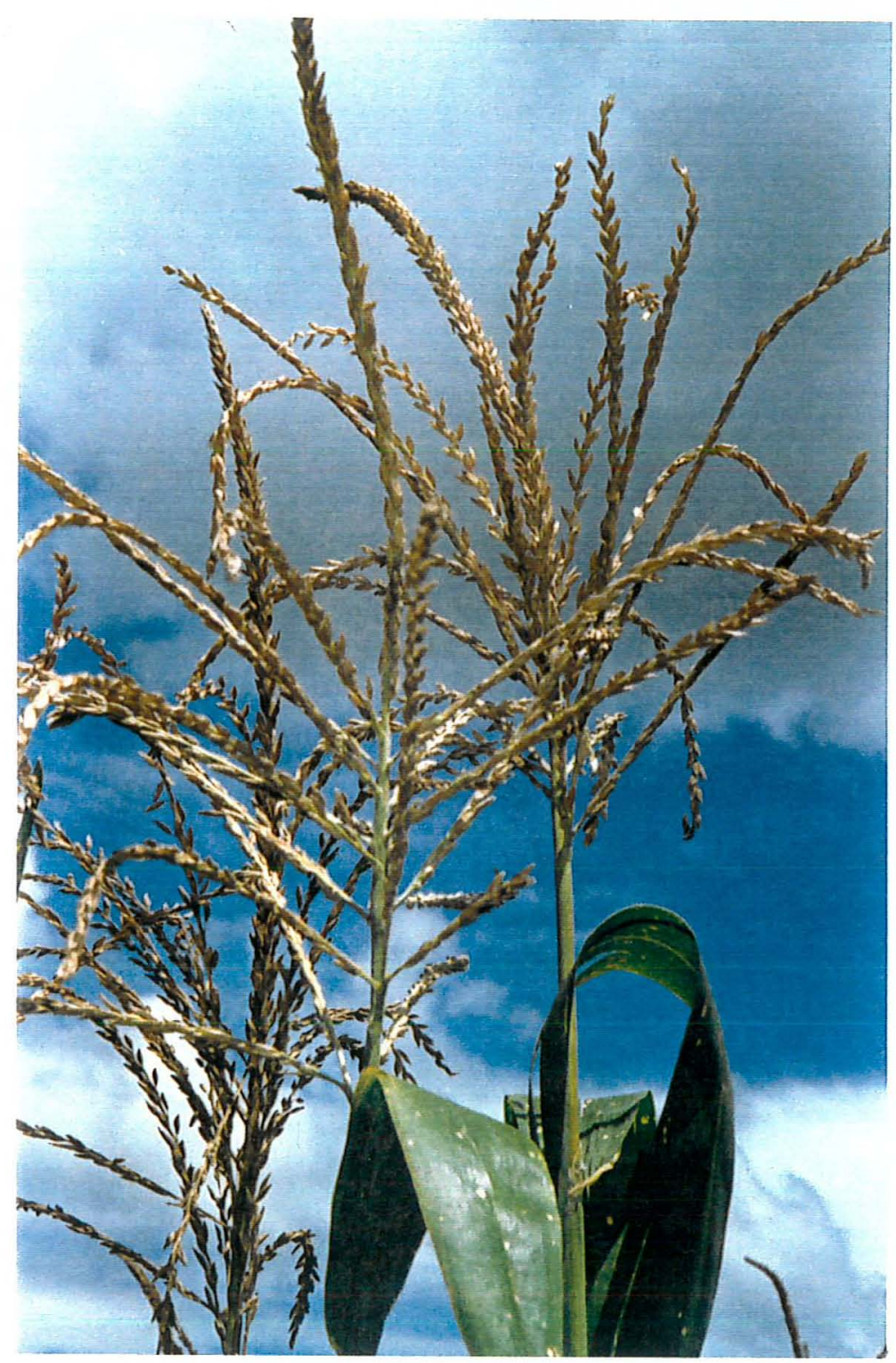

Figura 1: Plantas sem sintomas aparentes de infecção na parte superior classe 0 


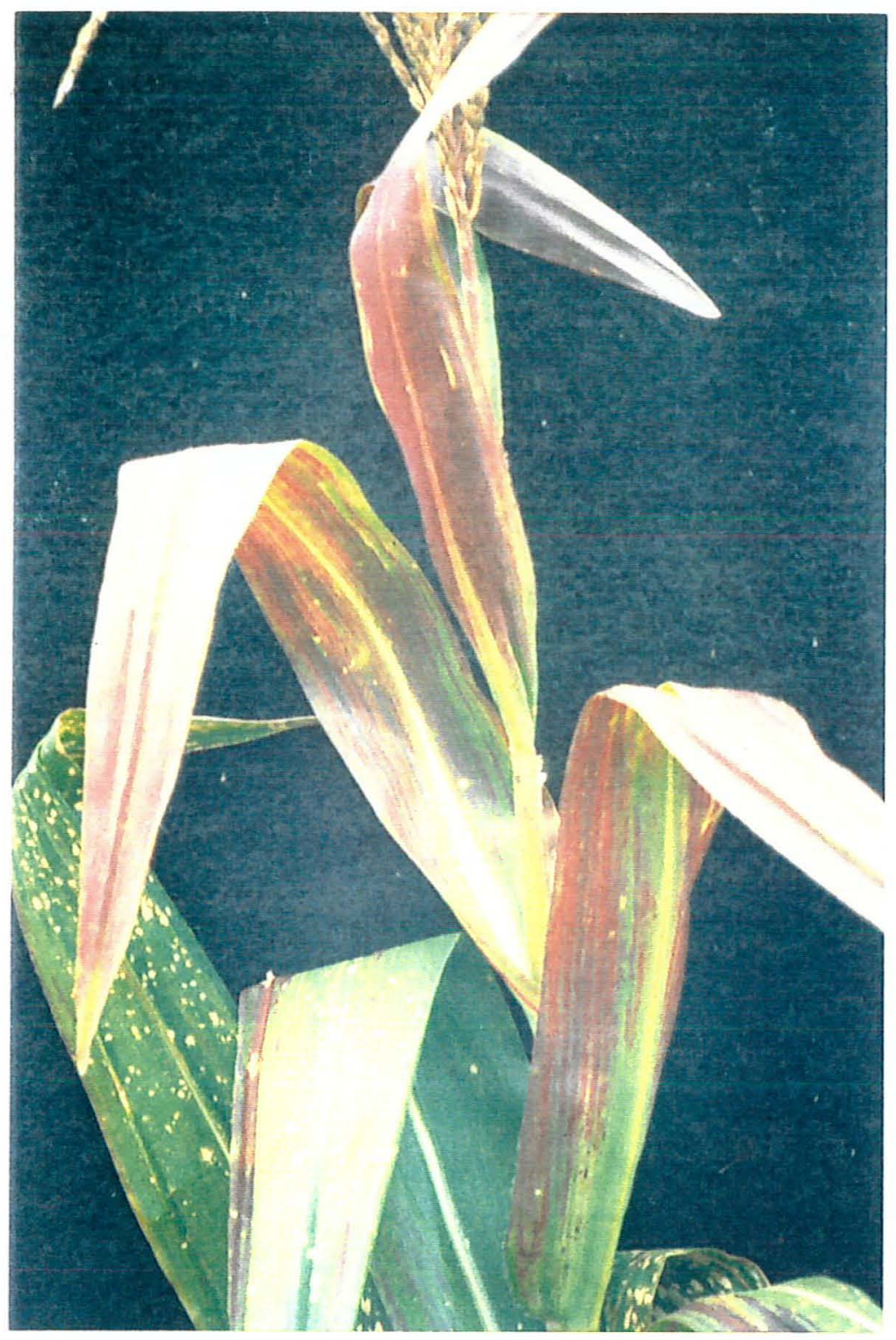

Figura 2: Plantas com bom desenvolvimento vegetativo, mas com avermelhamento das folhas superiores - classe 0,5 


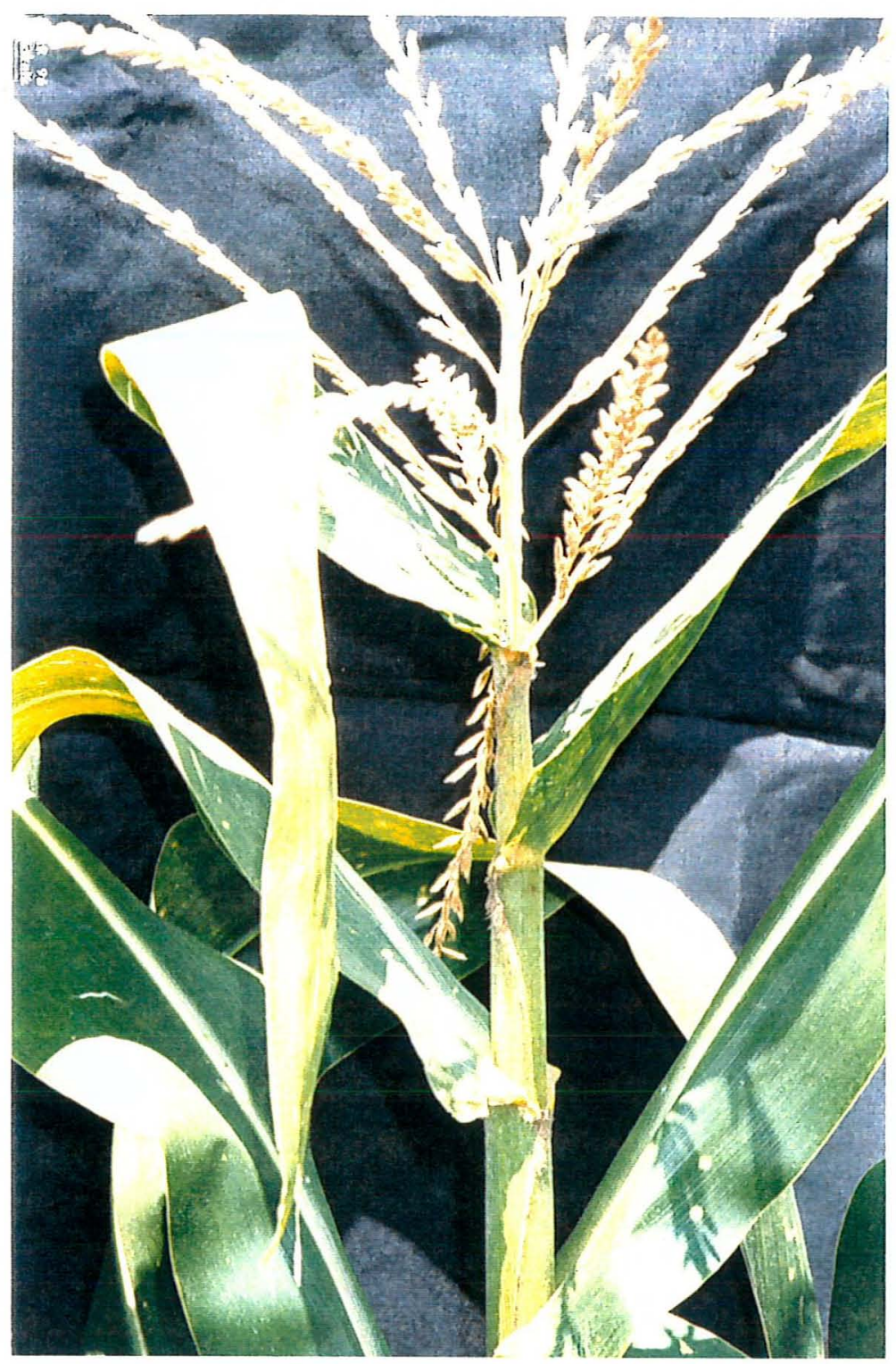

Figura 3: Planta apresentando leve redução no desenvolvimento dos últimos internódios, e emissão incompleta do pendão - classe 1 


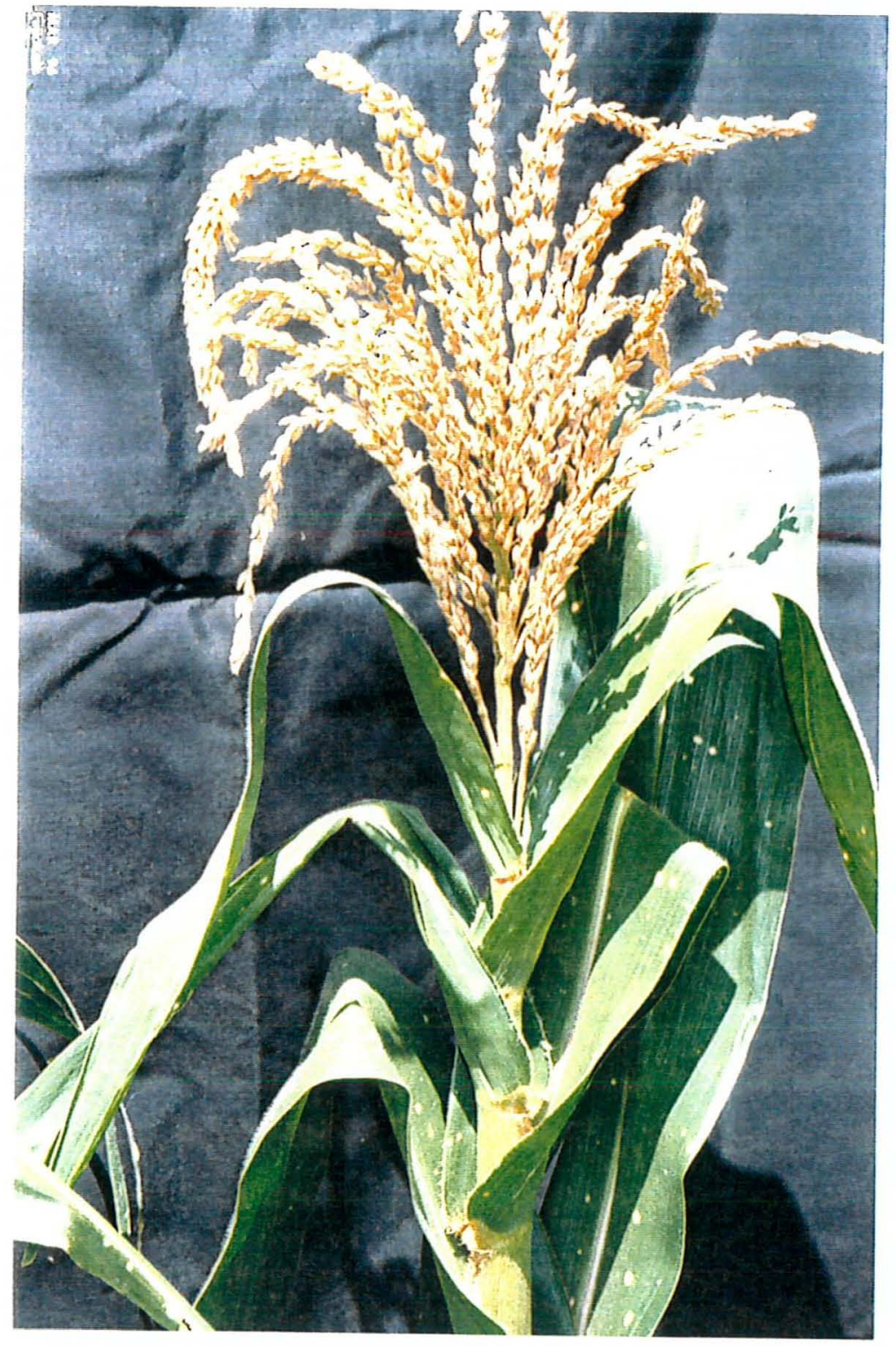

Figura 4: Planta apresentando encurtamento acentuado dos internódios superiores - classe 2 


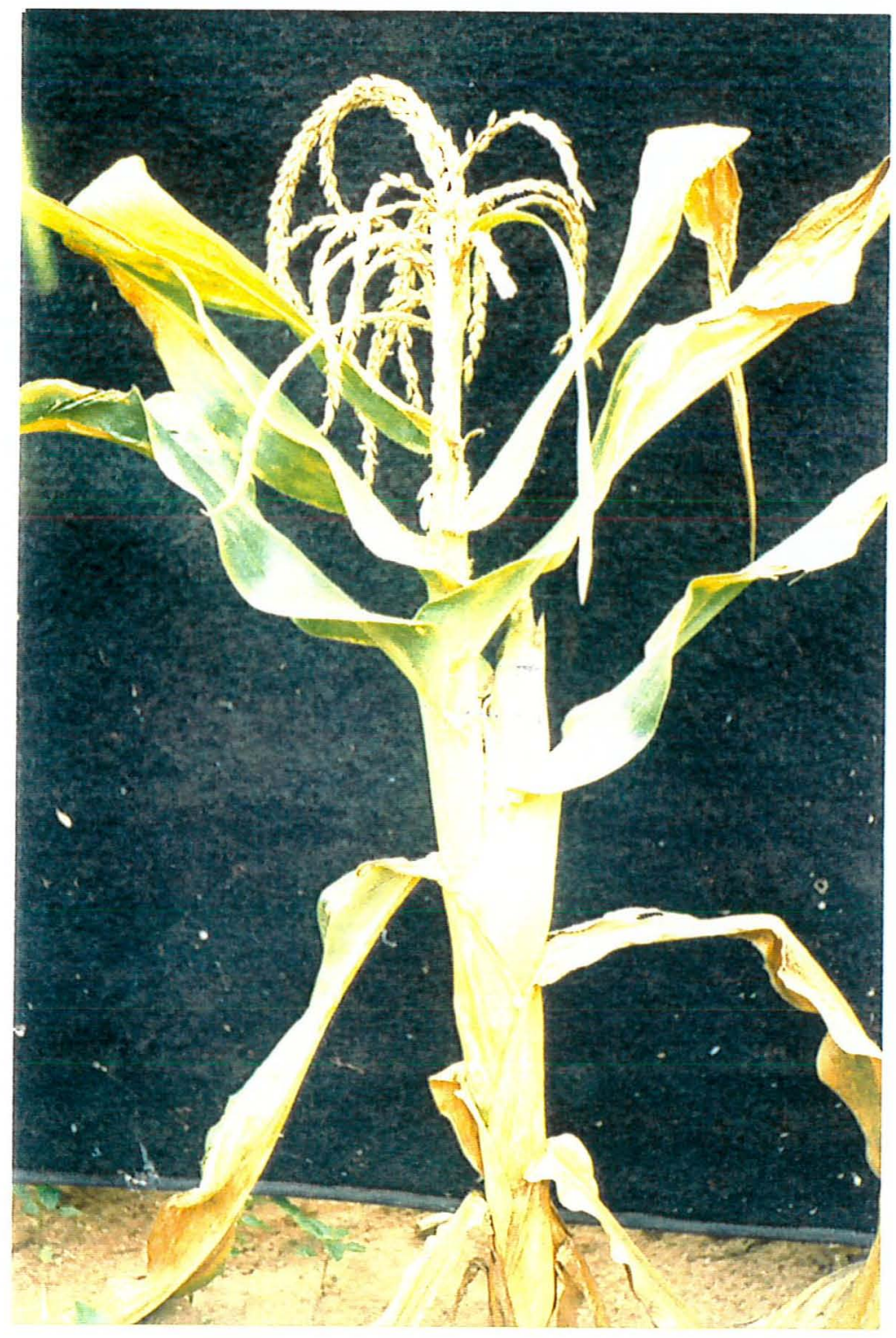

Figura 5: Planta apresentando redução drástica no desenvolvimento devido ao encurtamento dos internódios do terço superior - classe 3 


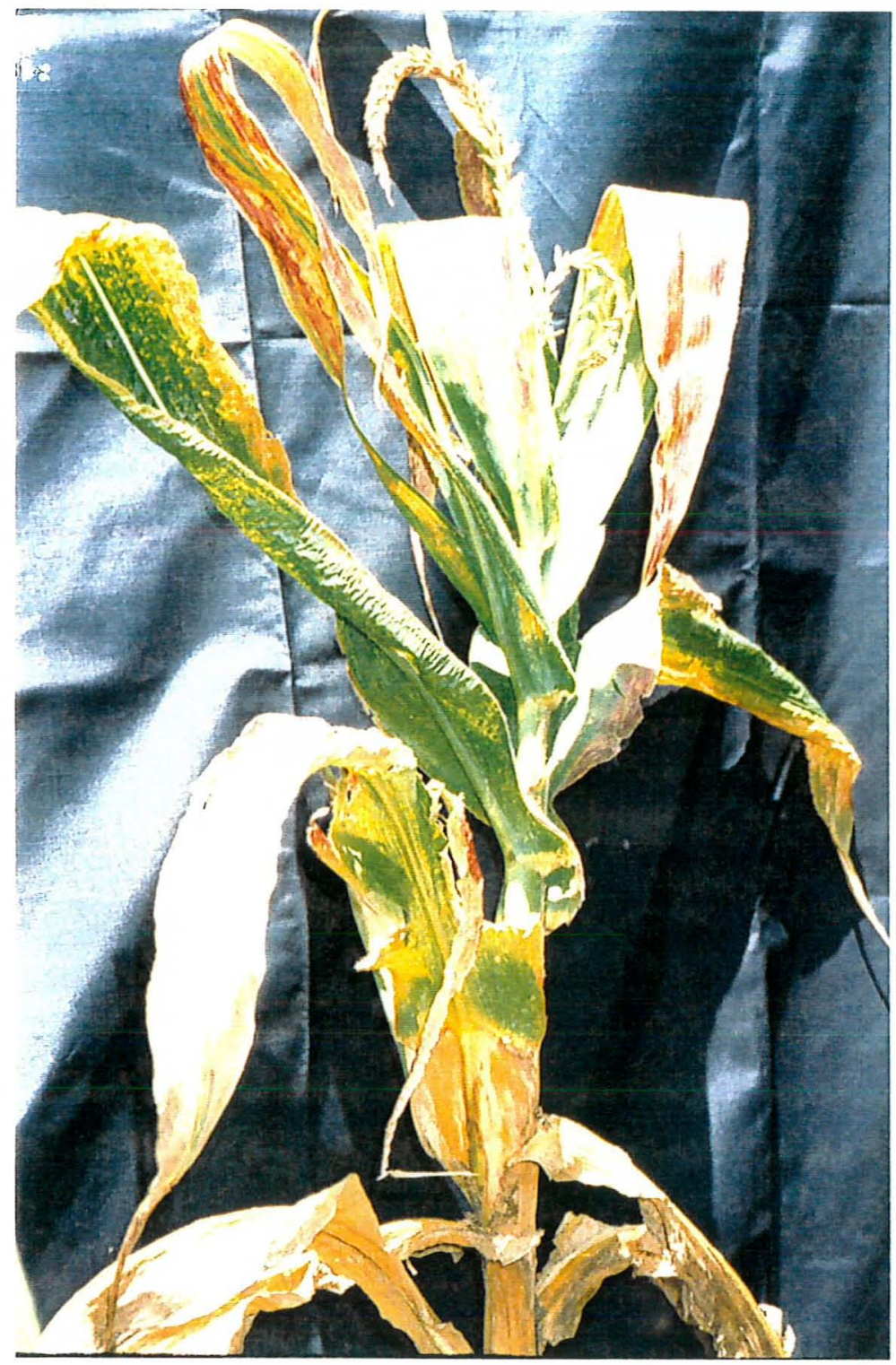

Figura 6: Planta apresentando sintomas característicos do "complexo", com enfezamento severo e redução dos internódios médios e superiores classe 4 
Os dados de severidade de infecção foram convertidos em niveis totais de resistência (NTR), form. (1)

$$
\mathrm{NTR}=f(0) \times(\mathrm{cmv}-0)+f(0,5) \times(\mathrm{cmv}-0,5)+\ldots+\mathrm{f}(\mathrm{cmv}) \times(\mathrm{cmv}-\mathrm{cmv})
$$

onde:

NTR = niveis totais de resistência;

$f()$ = frequência de plantas, em porcentagem, nas diferentes classes, variando de 0 à 4 ;

cmv = classe de maior valor, 4

\subsubsection{Respostas correlacionadas}

Foram realizadas as estimativas des respostas correlacionadas existentes entre a característica NTR com componentes de produção, não considerados no processo de seleção.

Componentes de produção avaliados:

a) peso de grãos, expresso em kg/parcela;

b) porcentagem de espigas sadias;

c) número de espigas por parcela;

d) altura da inserção da folha bandeira, expressa em metros;

e) altura da inserção da espiga superior, expressa em metros. 


\section{RESULTADOS E DISCUSSÃO}

\section{A.1 Materiais utilizados}

\subsubsection{Variedade sintética}

A variedade sintética de milho "Piranão de Inverno SM XIV" foi escolhida para o desenvolvimento deste trabalho devido a sua adaptação para a época de plantio tardio, pela variabilidade na reaçäo das plantas à infecçäo pelos agentes causais do enfezamento e certas viroses, e, pela importancia econômica assumida por esta enfermidade durante a época de plantio tardio. As perdas econômicas originárias destas infecções durante o período da "safrinha" foram relatadas por KITAJIMA \& COSTA (1972) e FERNANDES \& BALMER (1990).

A adaptação para a época de plantio tardio foi consequencia de um programa de melhoramento, iniciado em 1977 no Departamento de Genética, ESALONUSP, visando adaptar a variedade "Piranäo" para o plantio durante o periodo de inverno (BARBOSA et al, 1990). Foram realizados quatorze ciclos de seleção massal estratificada, seguindo a metodologia apresentada por LONNOUIST (1967). Os lotes de seleção foram sempre instalados na primeira quinzena de abril, em uma área de $6.000 \mathrm{~m}^{2}$. A pressão de seleçäo adotada era de $0,7 \%$ por ciclo, o que correspondia à, aproximadamente 200 plantas. 
A variabilidade na reação das plantas à infecção por fitoplasma, espiroplasma e vírus da risca foi detectada durante a fase de desenvolvimento desta variedade através de observações de campo.

\subsubsection{Padrōes de suscetibilidade}

A utilização dos padrōes de suscetibilidade é importante durante a fase de avaliação do progresso genético obtido com a seleção para doenças, sendo um indicador das condições do ambiente no decorrer deste procedimento, revelando a consistência dos dados obtidos.

No caso da seleçäo, realizada neste trabalho, para fitoplasma, espiroplasma e virus da risca, os padrões foram obtidos durante o segundo ciclo de seleção. Nesta fase, foi observado que, algumas progênies apresentavam fixada a reação de suscetibilidade, sendo, portanto, multiplicadas em ambiente não favorável ao desenvolvimento da enfermidade em estudo, a fim de possibilitar a obtenção de sementes destas.

\subsubsection{Hibrido comercial}

O hibrido comercial, $Z 8392$, foi escolhido para ser testemunha nos ensaios de avaliação, servindo como um referencial externo para os dados obtidos com a seleçäo realizada na variedade "Piranäo de Inverno SM XIV". 


\section{4 .2 Fases do método de seleção}

\subsubsection{Escolha da variedade}

A escolha da variedade pode ser realizada com base em dados experimentais ou no conhecimento prévio do material.

Neste estudo, procedeu-se a escolha da variedade sintética "Piranão de Inverno SM XIV", de acordo com o conhecimento prévio do material. Observaç̄ones feitas em condiçōes de campo, durante a fase de desenvolvimento da variedade, revelaram variabilidade na reação das plantas à infecção pelo "complexo" formado pelo vírus da risca, fitoplasma e espiroplasma.

A variabilidade foi mantida para a característica, mesmo depois da realização de quatorze ciclos de seleção massal estratificada, possibilitando, inclusive, a obtenção de padrōes de suscetibilidade, conforme será discutido posteriormente.

A necessidade de submeter esta variedade a um novo método de seleção, que proporcionasse maior nivel de resistência a este "complexo" era essencial, devido à adaptação desta variedade durante o período de plantio tardio, ocasiāo em que as perdas originárias das infecções causadas por esta enfermidade são significativas.

\subsubsection{Obtenção das progênies de meios irmãos}

A obtenção inicial de progênies de meios irmãos é indicada, em funçäo da maior variância genética aditiva dentro, apresentada por este tipo de progênie. Esta variância é explorada no trabalho de seleção realizado no método proposto. 
Diferentes métodos de seleção podem ser adotados para a obtenção das progênies. No caso deste trabalho, adotou-se o método de seleção massal estratificada (LONNQUIST, 1967), o qual já vinha sendo utilizado para o desenvolvimento da variedade sintética utilizada. Em um lote isolado de $6.000 \mathrm{~m}^{2}$, foram selecionadas 220 progênies de meios irmãos, que constituiram o XIV ciclo de seleção para maior adaptação ao período de plantio tardio, na variedade "Piranão".

\subsubsection{Uso de testemunha intercalar}

Indicada, inicialmente, para a avaliação de componentes de produçäo (GODOY, 1994), a testemunha intercalar representa um referencial para a escolha do ambiente, para o trabalho de seleção, e um indicador do progresso da seleçäo para o melhorista durante a atividade. Sua aplicação propicia a escolha do ambiente de seleção através da avaliação do comportamento das progênies de meios irmãos. Devido à instalação de uma repetição por ambiente, não acarreta restrição no número de sementes das progênies.

Recomenda-se a proporção de três fileiras de progênies para uma fileira da testemunha, que deve ser representada pela população origina! para indicar o progresso obtido durante o procedimento de seleção.

\subsubsection{Escolha do ambiente de seleção}

A seleção inicial das áreas experimentais foi devido à realização de plantio intensivo de milho durante o ano todo, favorecendo a existência de plantas em diferentes estádios de desenvolvimento vegetativo, o que, teoricamente, contribui para que as populações da cigarrinha Dalbulus maidis permaneçam infectivas, uma vez que a capacidade infectiva diminui com 
o tempo quando não há plantas infectadas para a alimentação do inseto vetor, conforme relatado por GAMEZ (1973).

Entretanto, na avaliação das 220 progênies de meios irmäos realizada em 1991 , maior incidencia e severidade da doença foram observadas na Estação Experimental de Anhembi, resultando na eliminação da área experimental do Departamento de Genética, correspondente ao local de desenvolvimento da variedade sintética, situada em Piracicaba, SP para fins de trabalho de seleção a partir de 1991, fase correspondente à escolha do ambiente para seleção do método em estudo.

Observações posteriores de campo, realizadas nas duas localidades, confirmaram as diferenças relatadas e a escolha acertada da Estação Experimental de Anhembi para o desenvolvimento deste trabalho. Não são conhecidas, ao certo, as causas das diferenças observadas entre estes locais, podendo existir, provavelmente, diferenças quanto à capacidade infectiva de população do inseto vetor elou, ainda, efeitos dos niveis de fertilidade dos solos, pois a área experimental do Departamento de Genética está situada em solo do tipo latossolo vermelho escuro, de alta fertilidade, enquanto a Estação Experimental de Anhembi em solo originário do arenito de Botucatu, possui baixo nivel de fertilidade. Este solo arenoso apresenta baixa capacidade de retenção de água, o que aumenta as condições de estresse a que são submetidas as plantas. O estresse hidrico associado ao desequilibrio nutricional podem ter influenciado na manifestaçäo do quadro sintomatológico devido à infecção pelo "complexo" formado pelo vírus da risca-fitoplasmaespiroplasma, o que confirmaria a hipótese de que plantas nutricionalmente equilibradas apresentam maior tolerância a infecçäo por patógenos (BEDENDO, 1995). 


\subsubsection{Aumento da endogamia dos genótipos selecionados}

Como característica peculiar deste método, são efetuadas, por ocasião do florescimento, polinizações manuais entre as plantas das progênies que apresentaram menor nivel de infeccão pelos agentes causais da enfermidade em estudo.

Nesta fase, é esperada baixa intensidade de seleçäo entre progênies e alta intensidade de seleção dentro das progenies. À medida que a característica vai sendo fixada, vai aumentando a uniformidade dentro das progênies até um limite, quando é atingida a homozigose, näo ocorrendo mais resposta à seleção. O número de geraçōes para fixar as reações das plantas, à infecção pelos patógenos avaliados, ó variável de acordo com o número de genes que controlam a característica e da base genética do material base de seleção. Outro fator, que irá determinar o momento da recombinação das progênies selecionadas, refere-se à diminuição do tamanho efetivo resultante da seleçäo efetuada entre progênies.

No caso da seleção realizada para elevar o nivel de resistência das plantas da variedade sintética "Piranão de Inverno SM XIV" à infecção pelos agentes causais do enfezamento, foram realizados quatro ciclos de seleção. As pressões de seleção entre progênies foram de $80,9 \%, 2,0 \%, 74,7$ $\%$ e $23,9 \%$, e dentro das progênies de $2,5 \%, 3,7 \%, 6,1 \%$ e $4,8 \%$ respectivamente, para os ciclos $\mathrm{Cl}$, CII, CII e CIV. Estes valores variaram de acordo com as condiçōes de ambiente, sendo consideradas excelentes estas condições durante o segundo ciclo de seleção. Nesta fase, o número de progênies originais ficou restrito em 43 . Embora, ainda, existisse variabilidade para a ceracterística, este foi considerado o momento de recombinação, em função do tamanho efetivo reduzido.

Se a intensidade de seleção tivesse sido menor para a obtenção do segundo ciclo de seleção, o processo de seleção poderia 
prosseguir enquanto existisse variabilidade para a característica. Considera-se que o avanço brando da endogamia, proporcionado pelo cruzamento entre plantas irmãs, contribui para a recombinação de combinações gênicas favoráveis à resistencia das plantas à infecção polos agentes causais do enfezamento.

Quando o objetivo do programa for seleção e obtenção de linhagens endogâmicas, o processo de seleção deverá prosseguir até a fixação da característica. No caso em estudo, ainda existia variabilidade após o quarto ciclo de seleção, ocasião em que as progênies possuiam, teoricamente $54,69 \%$ de endogamia.

Durante a realizaçäo do segundo ciclo de seleçäo, foi observado que algumas progênies apresentavam fixada a reaçäo de suscetibilidade das plantes à infecção pelos agentes causais do "complexo" formado pelo vírus da risca, fitoplasma e espiroplasma. Devido ̀̀ alta severidade dos sintomas expressos por estas, procedeu-se a identificação e a multiplicação destas na área experimental do Departamento de Genética, local onde os sintomas foram menos intensos, sendo possivel a obtenção de sementes. O pequeno número de gerações para fixar a suscetibilidade foi associada à observação de alta frequência de plantas apresentando um quadro sintomatológico relacionado ao enfezamento na população original, sugerindo a existência de poucos pares de genes atuando no controle da reação das plantas à infecção pelos agentes causais do enfezamento. Esta observação não contradiz os relatos da literatura (MARQUEZ SANCHEZ, 1982), que atribuem a herança da resistência como sendo de natureza quantitativa, porém sem definir o número de genes atuando no controle da mesma.

Em amostras de plantas infectadas, coletadas na Estação Experimental de Anhembi, foi detectada a presença de fitoplasma $e$ espiroplasma, inclusive com infecção mista (DAVIS et al, comunicação pessoal). Esta constatação confirma a interação existente entre os agentes 
causais do enfezamento (CHOUDHURY \& ROSENKRANZ, 1973; WOLANSKI \& MARAMOROSCH, 1979; BRADFUTE $\odot$ al, 1981; DAVIS, 1984; GORDON \& NAULT, 1977 a HARRISON et al, 1996), conferindo um quadro sintomatológico complexo. Esta interação dificulta o trabalho isolado de seleção para cada agente causal do complexo, conforme sugerido por SCOTT \& ROSENKRAZ (1977b).

Năo foi objetivo deste estudo avaliar qual o mecanismo de resistência envolvido, porém, deve-se considerar que os agentes vírus da risca, fitoplasma e espiroplasma, são transmitidos, em nossas condiçōes, pelo mesmo inseto vetor, a cigarrinha Dalbulus maidis (KITAJIMA \& COSTA, 1972; KITAUIMA \& COSTA, 1983), podendo existir reações das plantas que obstruem a infecção pela cigarrinha. Outro fato a ser considerado é que estes agentes ficam restritos ao floema das plantas infectadas (WOLANSKI \& MARAMOROSCH, 1979; HARRISON et al, 1996), de forma que, pode existir um mecanismo único de resistência das plantas à presença destes patógenos. Estudos complementares devem ser realizados no sentido de definir quais são estes mecanismos de resistência das plantas.

\subsection{Avaliaçãa do método}

O método em estudo foi sendo desenvolvido durante o procedimento de seleção para elevar o nível de resistência ao "complexo" formado pelo vírus da risca, fitoplesma e espiroplasma o potencial de sua aplicação está associado ao progresso genético proveniente de sua utilização.

A avaliação do progresso genético deve ser feita através dos componentes que melhor caracterizem a resposta do material à seleção realizada. Valores referentes à niveis totais de resistência elou frequência de plantas sadias são bons indicadores. Estes dados são obtidos, em condições 
de campo, mediante a aplicação de escalas diagramáticas desenvolvidas para a enfermidade em estudo ou adaptadas para a mesma.

A aplicação destas escalas deve ser feita no momento de melhor discriminação dos tratamentos, para isto diferentes leituras devem ser comparadas, uma vez que a evolução dos sintomas varia de acordo com as condiçōes de ambiente. No trabalho realizado, foram consideradas as leituras de severidade de infecção efetuadas com 20,27,14 e 16 dias após 0 florescimento médio dos experimentos $1,2,3$ e 4 , respectivamente. Os experimentos 3 e 4 foram instalados durante os meses de fevereiro e março do ano de 1996, período correspondente ao plantio tardio ou "safrinha", ocasião em que são intensos os danos causados pelo enfezamento (KITAJIMA \& COSTA, 1972; FERNANDES \& BALMER, 1990). Por esta razão, foi possivel a discriminação dos tratamentos com duas semanas após o florescimento feminino das parcelas. Após este período, já foram observadas plantas com morte promatura, condição esta associada ao quadro sintomatológico resultante da infecção pelos agentes do "complexo", motivo principal da eliminação das leituras posteriores.

A avaliação do progresso genético obtido foi feita em condições favoráveis à infecção natural, conforme evidenciado na Figura 7, na qual é demonstrada a alta frequência de plantas infectadas para o padrão de suscetibilidade ao lado do terceiro ciclo de seleção para resistência ao complexo, o qual, embora tenha sido submetido à mesma população do inseto vetor, a cigarrinhe Dalbulus maidis, não evidenciou sintomas severos resultantes da infecçäo. Esta observação comprova a importância da utilização de padrōes de suscetibilidade em ensaios de avaliação de doenças, pois revelam se as condições do ambiente foram favoráveis ou não ao desenvolvimemento de epidemias mediante inoculaçäo artificial ou infecção natural, e, consequentemente, revelam a consistência dos dados obtidos. 


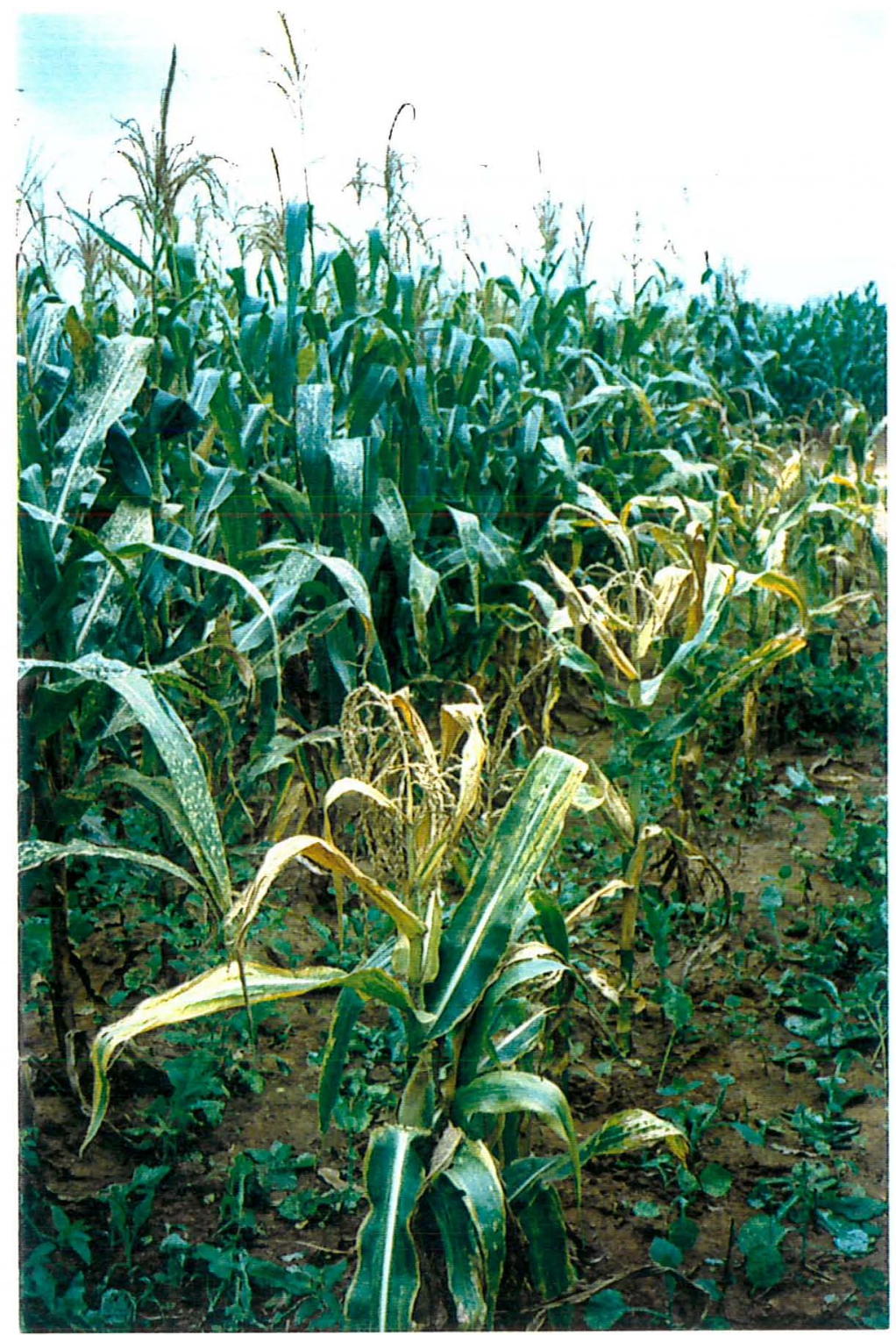

Figura 7: Uniformidade de infecção apresentada pela progênie PS 135.1.1 à direita, comparada ao tratamento correspondente ao terceiro ciclo de seleção à esquerda. 


\subsection{Aplicação do método}

\section{$4,4.1$ Severidade de infecção}

Para melhor visualização dos resultados, os dados de severidade de infecção foram transformados em niveis totais de resistencia (NTR), conforme demonstração feita ne fórmula 1. A análise desta característica resultou nas mesmas conclusões da análise realizada com os valores médios das notas atribuídas às plantas das parcelas

A seguir serão apresentadas as análises de variância realizadas para niveis totais de resistência (NTR). Inicialmente, foi efetuada a análise conjunta de variância (Tabela 2).

Tabela 2: Análise conjunta de variância da característica:

Niveis Totais de Resistência (NTR).

\begin{tabular}{l|rrrr}
\hline F.V. & G.L. & \multicolumn{1}{c}{ S.Q. } & \multicolumn{1}{c}{ Q.M. } & \multicolumn{1}{c}{$F$} \\
\hline Rep. & 9 & $8.980,90$ & 997,878 & 1,13 \\
Época & 3 & $39.399,50$ & $13.133,166$ & $14,91^{\star *}$ \\
Trat. & 9 & $1.865 .166,96$ & $207.240,773$ & $235,21^{\star *}$ \\
Ep $\times$ Tr. & 27 & $140.100,88$ & $5.188,921$ & $5,89^{\star *}$ \\
Erro & 351 & $309.260,93$ & 881,085 & \\
\hline
\end{tabular}

C.V. $(\%)=9,76$

Porém, como existiu significância para a interação época $\times$ tratamento, foram realizadas as análises de variância para cada experimento conduzido, conforme orientação dada por GOMES (1990), (Tabolas 3 - 6). 
Tabela 3: Análise de variancia da característica: Niveis Totais de Resistência (NTR), experimento 1

\begin{tabular}{l|rrrr}
\hline F.V. & G.L. & \multicolumn{1}{c}{ S.Q. } & \multicolumn{1}{c}{ Q.M. } & \multicolumn{1}{c}{ F. } \\
\hline Rep. & 9 & $10.309,84$ & $1.145,538$ & 1,92 \\
Trat. & 9 & $330.649,89$ & $36.738,877$ & $61,58^{\text {** }}$ \\
Erro & 81 & $48.324,77$ & 596,602 & \\
\hline
\end{tabular}

C.V. $(\%)=7,77$

0 experimento 1 , instalado durante o mês de novembro, representou um periodo em que os danos resultantes da enfermidade em estudo não são representativos, não sendo, portanto, detectada diferença significativa entre os diferentes ciclos de seleção em relação à população original (Tabelas 3 e 7). Entretanto, já neste período foi possível a constatação da tendência em maior nivel de resistência dos materiais selecionados, na magnitude de $3,2 \%$ após o quarto ciclo de seleção.

Tabela 4: Análise de variância da caracteristica: Niveis Totais de Resistência (NTR), experimento 2.

\begin{tabular}{l|rrrc}
\hline F.V. & G.L. & \multicolumn{1}{c}{$S . Q}$. & \multicolumn{1}{c}{ Q.M. } & \multicolumn{1}{c}{$F$} \\
\hline Rep. & 9 & $11.064,88$ & $1.229,431$ & 2,63 \\
Trat. & 9 & $833.240,89$ & $92.582,321$ & $198,15^{* *}$ \\
Erro & 81 & $37.846,13$ & 467,236 & \\
\hline
\end{tabular}

C.V. $(\%)=6,95$

Nos experimentos 2 e 3 , instalados durante os meses de janeiro e fevereiro, respectivamente, foi possivel distinguir da população original, estatisticamente, ao nivel de $5 \%$ de significância, os níveis de resistência obtidos após o terceiro ciclo de seleção. $O$ ganho obtido após o 
quarto ciclo de seleção foi estimado, nestes experimentos, em $4,8 \%$ e $11,0 \%$ (Tabelas $4,5 \odot 7$ ).

Tabela 5: Análise de variancia da característica: Niveis Totais de Resistência (NTR), experimento 3.

\begin{tabular}{l|rrrr}
\hline F.V. & G.L. & \multicolumn{1}{c}{$S . Q}$. & \multicolumn{1}{c}{ Q.M. } & \multicolumn{1}{c}{$F$} \\
\hline Rep. & 9 & $8.663,51$ & 962,612 & 0,52 \\
Trat. & 9 & $458.005,99$ & $50.889,554$ & $27,62^{* *}$ \\
Erro & 81 & $149.236,43$ & $1.842,425$ & \\
\hline
\end{tabular}

$C V .(\%)=14,86$

A maior severidade de infecção foi observada no experimento 3; uma semana após o florescimento, já era evidente alta frequencia de morte prematura das plantas, associada a sintomas de avermelhamento ou amarelecimento das folhas. Esta observação foi mais intensa em algumas repetições, razão pela qual foi obtido, neste experimento, o maior coeficiente de variação ambiental, $14,86 \%$

No experimento 4 , a diferença minima significativa entre população original e selecionadas é obtida a partir do quarto ciclo de seleção (Tabelas 6 e 7), sendo a estimativa do ganho, após este ciclo, de $5,6 \%$.

Tabela 6: Análise de variância da característica: Niveis Totais de Resistência (NTR), experimento 4.

\begin{tabular}{l|rrrc}
\hline F.V. & G.L. & \multicolumn{1}{c}{ S.Q. } & \multicolumn{1}{c}{ Q.M. } & \multicolumn{1}{c}{ F. } \\
\hline Rep. & 9 & $9.520,40$ & $1.057,822$ & 1,98 \\
Trat. & 9 & $383.371,08$ & $42.596,786$ & $79,73^{* *}$ \\
Erro & 81 & $43.275,86$ & 534,270 & \\
\hline
\end{tabular}

C.V. $(\%)=7,65$ 
Tabela 7: Médias obtidas para niveis totais de resistência nos quatro experimentos conduzidos na Estação Experimental de Anhembi, Piracicaba, SP, em $95 / 96$.

\begin{tabular}{l|rrrrr}
\hline \multicolumn{1}{c|}{ Trat. } & Exp. 1 & Exp. 2 & Exp. 3 & Exp. 4 & Média \\
\hline $\begin{array}{l}\text { Piranão de } \\
\text { Inverno SM }\end{array}$ & $345,60 \mathrm{a}$ & $331,60 \mathrm{~cd}$ & $308,00 \mathrm{abc}$ & $320,40 \mathrm{~b}$ & 326,40 \\
XIII & & & & & \\
Piranão de & $347,60 \mathrm{a}$ & $349,20 \mathrm{bc}$ & $312,80 \mathrm{abc}$ & $333,20 \mathrm{~b}$ & 335,70 \\
Inverno SM & & & & & \\
XIV & & & & & \\
Ciclo I & $338,40 \mathrm{ab}$ & $339,60 \mathrm{bc}$ & $289,07 \mathrm{bc}$ & $320,40 \mathrm{~b}$ & 321,87 \\
Ciclo II & $343,64 \mathrm{a}$ & $354,80 \mathrm{bc}$ & $311,60 \mathrm{abc}$ & $333,60 \mathrm{~b}$ & 335,91 \\
Ciclo III & $350,40 \mathrm{a}$ & $363,60 \mathrm{ab}$ & $347,60 \mathrm{ab}$ & $335,20 \mathrm{~b}$ & 349,20 \\
Ciclo IV & $358,80 \mathrm{a}$ & $366,00 \mathrm{ab}$ & $347,20 \mathrm{ab}$ & $352,00 \mathrm{ab}$ & 356,00 \\
PS 47.1 & $219,21 \mathrm{c}$ & $258,20 \mathrm{e}$ & $212,00 \mathrm{~d}$ & $214,43 \mathrm{~d}$ & 225,96 \\
PS 135.1.1 & $187,12 \mathrm{c}$ & $58,16 \mathrm{f}$ & $130,63 \mathrm{e}$ & $163,10 \mathrm{e}$ & 134,75 \\
PS 10.1.3 & $306,90 \mathrm{~b}$ & $301,96 \mathrm{~d}$ & $263,23 \mathrm{~d}$ & $279,63 \mathrm{c}$ & 287,93 \\
Z 8392 & $345,60 \mathrm{a}$ & $389,20 \mathrm{a}$ & $365,60 \mathrm{a}$ & $370,00 \mathrm{a}$ & 367,60 \\
\multicolumn{1}{c}{ Média } & 314,33 & 311,23 & 288,77 & 302,20 & 304,13 \\
\hline
\end{tabular}

Nivel de significância: Tukey, 0,05.

O ganho médio estimado foi de $6,05 \%$ representando $1,5 \%$ por ciclo, valor considerado bom. Embora, não tenha sido detectada diferença significativa entre os ciclos de seleção e a população original, foi mantida uma tendência de aumento no nivel de resistência das plantas à infecção pelo vírus da risca, fitoplasma e espiroplasma, demonstrada na Figura 8 , sendo observado que, à medida que se avançou com o processo, ocorreu aumento no nivel total de resistencia. Este aumento foi representativo a partir do terceiro ciclo de seleção, indicando que para esta característica faz-se necessário um certo nivel de endogamia para melhor discriminação das reações das plantas. Desta forma, não é desejável o estabelecimento de alta intensidade de seleção 
no início do programa de seleção, como foi a adotada no segundo ciclo de seleção deste trabalho.

A ausência de significancia estatística entre os ciclos de seleção e a população original pode estar associada ao local da obtenção das progênies de meios irmãos. A seleção das 220 progênies de meios irmãos foi realizada, para características agronômicas, em ambiente onde não houve a manifestaçäo de sintomas provenientes da infecçäo pelo "complexo". Se tivessem sido selecionadas no Anhembi, provavelmente, os ganhos teriam sido maiores.

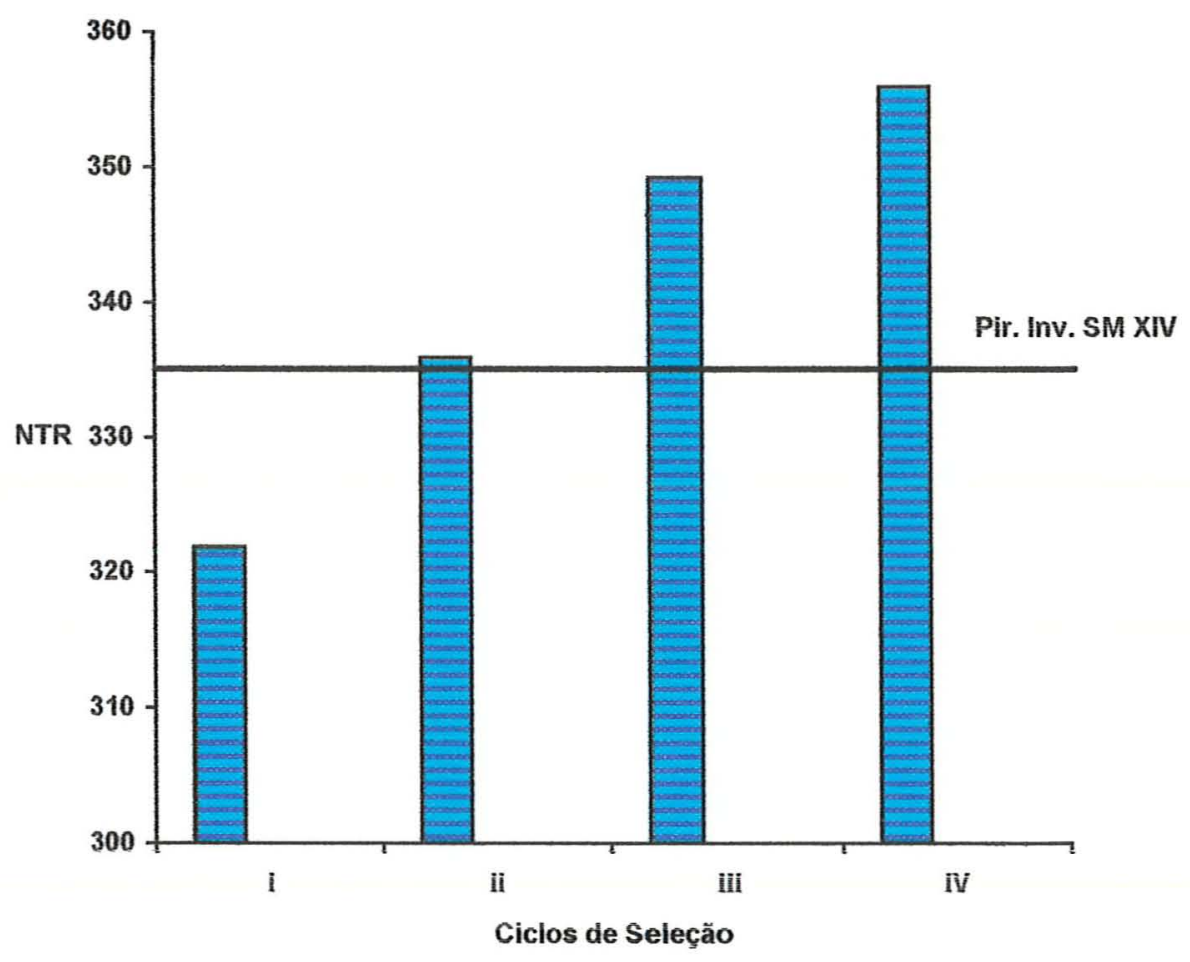

Figura 8: Médias obtidas para Níveis Totais de Resistência (NTR), nos quatro experimentos conduzidos na Estação Experimental de Anhembi, Piracicaba, SP, em 95/96. 
Quando as condições de ambiente para a seleção são favoráveis, como no presente estudo, deve-se considerar o início do programa com maior número de progênies, fato este viável devido à utilização da testemunha intercalar.

Associado ao ganho, observado para niveis totais de resistencia, foi obtido um aumento na frequência de plantas sem sintomas aparentes de infecção, ou seja, de plantas pertencentes à classe 0 , da ordem de $31,24 \%$ após o quarto ciclo de seleção (Tabela 8 , Figura 9).

Tabela 8: Porcentagem média de plantas sem sintomas evidentes de enfezamento, nos quatro experimentos conduzidos na Esteção Experimental de Anhembi, Piracicabe, SP, em $95 / 96$.

\begin{tabular}{lr|rrrrr}
\hline \multicolumn{2}{l|}{ Tratamento } & Exp. 1 & Exp. 2 & Exp. 3 & Exp. 4 & Média \\
\hline $\begin{array}{l}\text { Piranão } \\
\text { Inverno }\end{array}$ & de & 62,8 & 54,4 & 37,2 & 39,2 & 48,4 \\
XIII & & & & & \\
$\begin{array}{l}\text { Piranão } \\
\text { Inverno }\end{array}$ & SM & 62,4 & 62,4 & 42,0 & 43,2 & 52,5 \\
XIV & & & & & \\
Ciclo I & 57,2 & 60,8 & 38,0 & 37,2 & 48,3 \\
Ciclo II & 61,1 & 65,6 & 36,4 & 47,6 & 52,7 \\
Ciclo III & 62,8 & 71,2 & 58,8 & 46,8 & 59,9 \\
Ciclo IV & 72,4 & 76,0 & 64,0 & 63,2 & 68,9 \\
PS 47.1 & 3,8 & 6,5 & 2,0 & 0,0 & 3,1 \\
PS 135.1.1 & 1,2 & 0,0 & 0,8 & 0,0 & 0,5 \\
PS 10.1.3 & 42,4 & 35,0 & 19,7 & 23,2 & 30,1 \\
Z 8392 & 54,4 & 96,4 & 88,4 & 73,6 & 78,2 \\
Média & 48,0 & 52,8 & 38,7 & 37,4 & 44,3 \\
\hline
\end{tabular}


Estes resultados indicaram que a aplicação deste método permifiu ganhos não somente para frequência de plantas sadias, conforme relatos da literatura (SCOTT \& ROSENKRAZ, 1974), mas também para severidade de infecção, sendo os valores evidenciados após a recombinação das progênies.

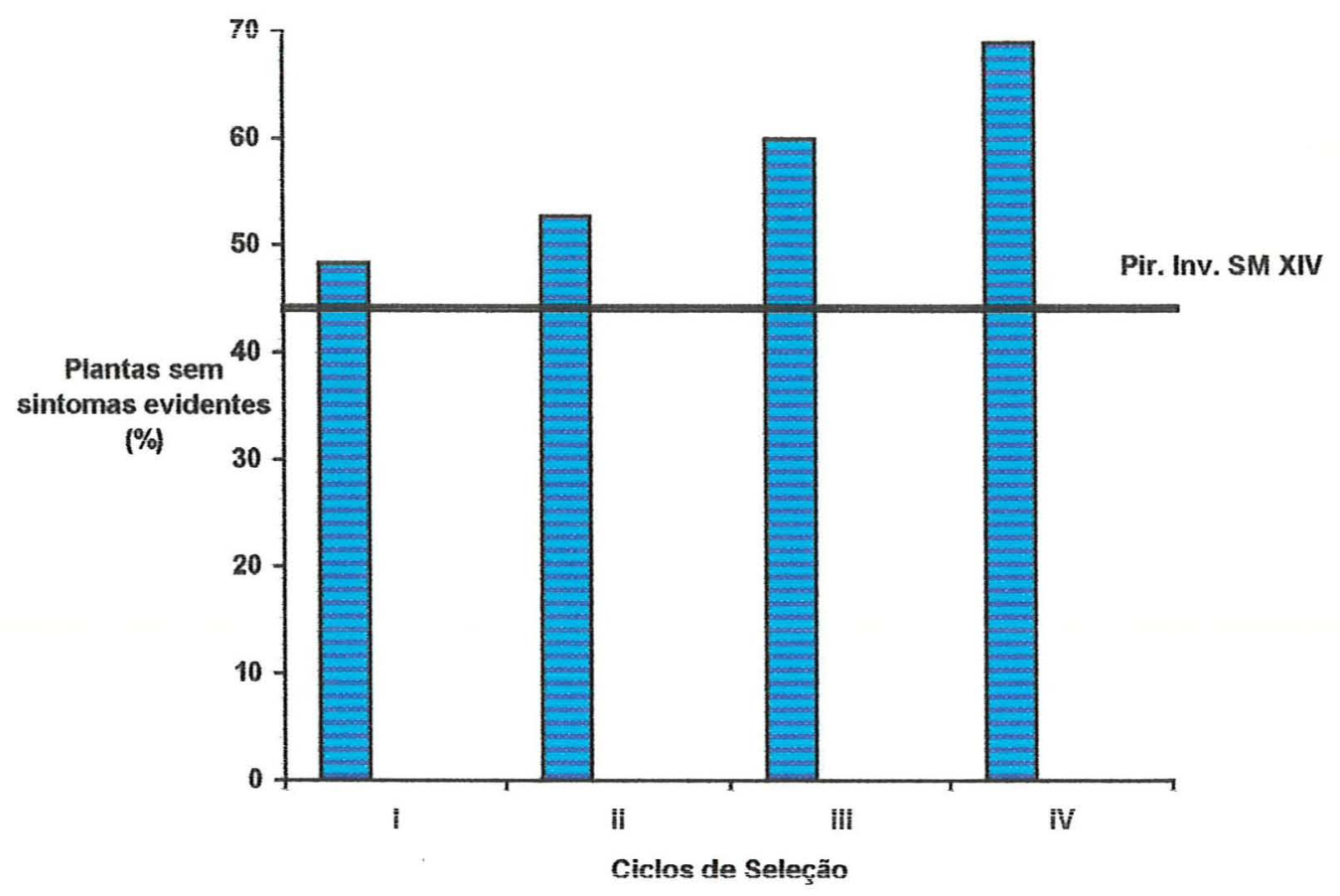

Figura 9: Módias obtidas para porcentagem de plantas sem sintomas evidentes de enfezamento, nos quatro experimentos conduzidos na Estaçåo Experimental de Anhembi, Piracicaba, SP, em 95/96. 


\section{4,42 Respostas correlacionadas}

Com relaçäo aos componentes de produção avaliados, foi observado que, embora näo tenham sido considerados no processo de seleçäo, a resposta foi correlacionada com os niveis totais de resistência dos materiais, demonstrando a importancia do aspecto sanidade no melhoramento de populações. O parâmetro utilizado neste trabalho possibilitou preservar o potencial de produtividade da variedade sintética "Piranão de Inverno SM XIV".

Para a característica peso de grãos, foi obtido um aumento de $3,33 \mathrm{~kg} /$ parcela na população original para $3,67 \mathrm{~kg} /$ parcela após o quarto ciclo de seleção (Tabela 9, Figura 10), representando um ganho de $10,40 \%$, ou de 2,6\%, em média, por ciclo de seleção. Este valor foi atribuído aos efeitos da infecção pelo vírus da risca, fitoplasma e espiroplasma nas plantas da variedade sintética, sendo o coeficiente de correlação entre NTR e peso de grãos estimado em 0,69 , estimativa semelhante à obtida por NELSON \& SCOTT (1973)

A estimativa do ganho obtido para peso e grãos é elevada, se considerarmos que com a realização do XIV ciclo de seleção massal estratificada foi obtido um ganho médio de $8,3 \%$, ocasião em que foram observadas, somente, características agronomicas favoráveis (Tabela 9).

As estimativas dos coeficientes de correlação existentes entre NTR e altura da inserção da folha bandeira e da espiga superior foram de 0,72 e 0,45 ,respectivamente. O maior valor observado entre NTR e altura da inserçäo da folha bandeira foi devido à redução nos internódios superiores causada pela infecção. 
Tabela 9: Valores médios observados para os componentes de produção avaliados nos quatro experimentos conduzidos na Estação Experimental de Anhembi, Piracicaba, SP, em 95/96.

\begin{tabular}{lr|ccccc}
\hline Tratamento & $\begin{array}{c}\text { Peso } \\
\text { de } \\
\text { Grãos } \\
\left(\mathrm{kg} / 10 \mathrm{~m}^{2}\right)\end{array}$ & $\begin{array}{c}\text { Altura } \\
\text { de } \\
\text { Planta } \\
(\mathrm{m})\end{array}$ & $\begin{array}{c}\text { Altura } \\
\text { de } \\
\text { Espiga } \\
(\mathrm{m})\end{array}$ & Prolificidade & $\begin{array}{c}\text { Espigas } \\
\text { Sadias }\end{array}$ \\
\hline $\begin{array}{l}\text { Piranão } \\
\text { Inverno }\end{array}$ & $\mathrm{SM}$ & 3,072 & 1,467 & 0,769 & 0,84 & 84,66 \\
$\begin{array}{l}\text { XIII } \\
\text { Piranão }\end{array}$ & de & 3,326 & 1,448 & 0,760 & 0,86 & 89,04 \\
Inverno & $\mathrm{SM}$ & & & & & \\
XIV & & & & & & \\
Ciclol & 3,121 & 1,416 & 0,745 & 0,84 & 86,67 \\
Ciclo II & 3,316 & 1,410 & 0,713 & 0,85 & 84,96 \\
Ciclo III & 3,453 & 1,474 & 0,753 & 0,87 & 85,41 \\
Ciclo IV & 3,672 & 1,486 & 0,790 & 0,90 & 83,89 \\
PS 47.1 & 1,949 & 1,295 & 0,672 & 0,70 & 76,36 \\
PS 135.1.1 & 0,800 & 0,925 & 0,505 & 0,59 & 67,24 \\
PS 10.1.3 & 2,633 & 1,408 & 0,718 & 0,87 & 87,02 \\
Z 8392 & 4,036 & 1,508 & 0,706 & 0,95 & 92,45 \\
Média & 2,938 & 1,384 & 0,713 & 0,83 & 83,77 \\
\hline
\end{tabular}

Para prolificidade, a estimativa do coeficiente de correlação foi de 0,57 . Esta característica está associada à paralização do desenvolvimento da inflorescência, em um estádio aqui denominado de "pré-boneca", correspondente ao período anterior à emissão do estilo - estigma, ou devido ao atraso na emissão do estilo - estigme. $O$ atraso na emissão do estilo estigma foi evidente nos padrões de suscetibilidade, de tal forma que, quando ocorria, já não havia polén para a fertilização, resultando na não formação de espigas. 
Com relação à porcentagem de espigas sadias foi obtido um valor de 0,58 , uma vez que foram consideradas doentes as espigas com sintomas de infecção e, também, as espigas mal formadas, as quais foram resultantes da interrupção do ciclo vegetativo da planta devido à infecção pelos agentes do enfezamento.

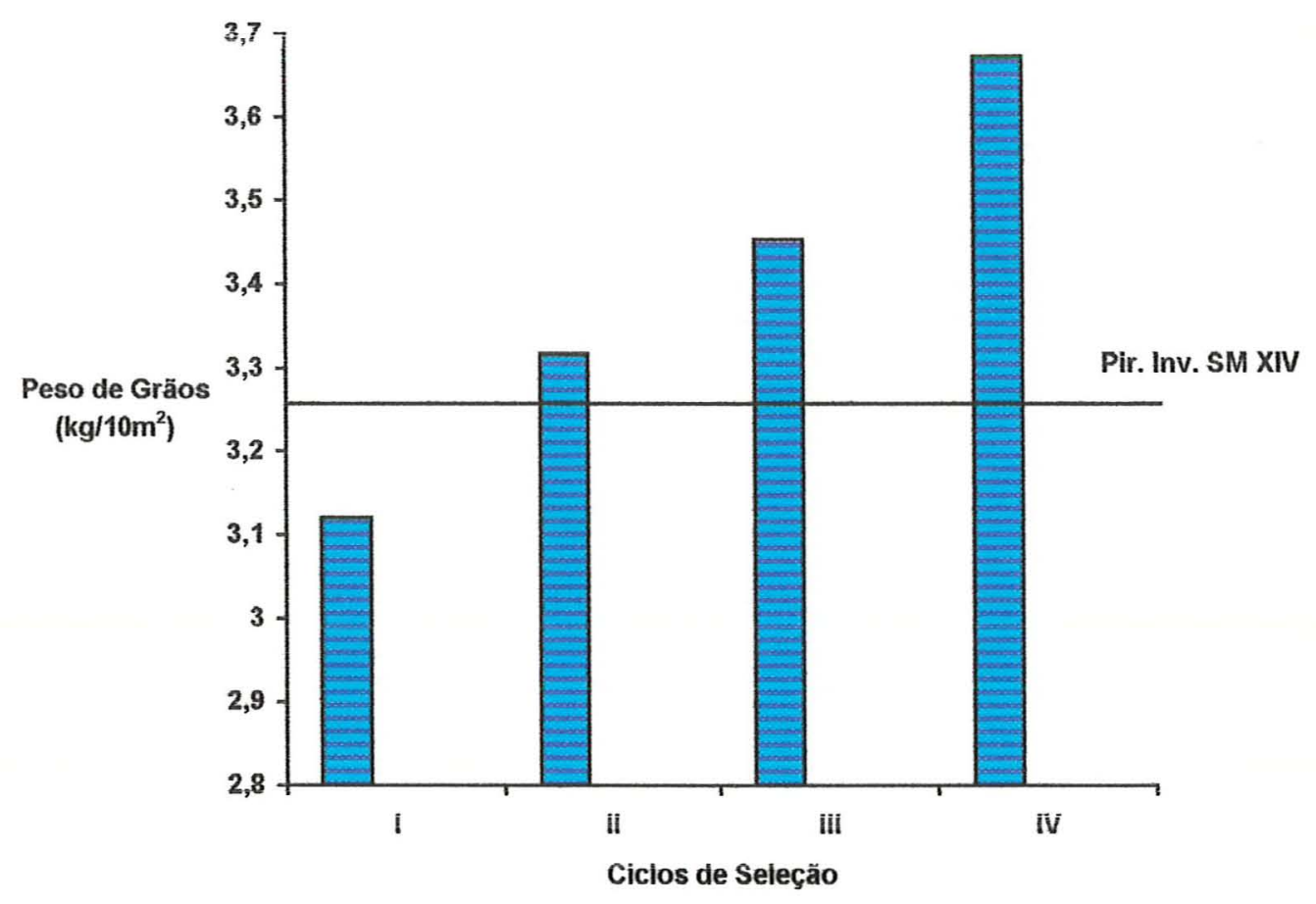

Figura 10: Médias obtidas para peso de grãos, nos quatro experimentos conduzidos na Estaçäo Experimental de Anhembi, Piracicaba, SP, em $95 / 96$. 


\section{Consideraçõos gorais}

A eficiência do método proposto está associada à:

a) escolha próvia do local @ da época que favoreçam o desenvolvimento de doença na variedade a ser selecionada.

As metodologias para esta escolha säo diversas, podendo ser, até mesmo, o conhecimento que o melhororista tem das áreas experimentais disponiveis para o trabalho.

b) uso intercalar da população original entre as fileiras das progênies, permitindo a instalação de apenas uma repetição por ambiente na fase de escolha do local e época para realizar a seleção e servindo como referência na seleção das progênies, evidenciando o progresso obtido durante as atividades de seleção.

A possibilidade da instalação de uma repetição por ambiente é importante na fase inicial do programa, podendo ser feita através de avaliação de progênies em diferentes locais e épocas, sem que ocorra limitaçäo no número de sementes disponive!.

A referência da testemunha para o processo de seleção possibilita que este procedimento seja realizado na repetição em que a característica é avaliada, viabilizando o trabalho com maior número de progênies, acima de duzentas. Número elevado de progênies é desejável para a aplicação do método, pois ele estabelece varias gerações de seleção para depois realizar o recombinação. Esta característica reduz, sensivelmente, a representatividade das progônies. No caso da seleção realizada para elevar o nivel de resistencia ao vírus de risca, fitoplasma e espiroplasma, foi considerado restrito o número de 220 progênies, uma vez que o tamanho efetivo ficou restrito a 43 plantas após o segundo ciclo de seleção. 
c) Uso incial de progênies de meios irmäos.

A escolha de progênies de meios irmãos para o inicio do trabalho de seleção foi devido a maior variância genética aditiva existente dentro deste tipo de progênie, a qual é explorada pela ênfase dada por este método à seleção dentro das progênies. A eliminação de progênies é consequência da seleção realizada dentro das mesmas.

d) avanço brando da endogamia e consequente aumento gradativo na frequência de genes favoráveis dentro das progênies, devido à recombinação estabelecida.

Para a seleção realizade para resistência ao vírus da risca, fitoplasma e espiroplasma, esta característica do método foi desejável, permitindo melhor discriminação dos materiais quando as progênies atingiram o nivel teórico de $31,25 \%$ de endogamia. 


\section{CONCLUSÕES}

As conclusões obtidas neste trabalho foram as seguintes:

1) O método em estudo foi eficiente para a seleção realizada para maior nivel de resistencia ao "complexo" formado pelo vírus de risca-fitoplasmaespiroplasma. Sua aplicação, na variedade sintética "Piranão de Inverno SM XIV", conferiu, após quatro ciclos de seleção, aumento de $6,05 \%$ no nivel total de resistência das plantas e de $31,24 \%$ na frequência de plantas sadias;

2) Associada a este aumento no nivel de resistência das plantas ocorreu aumento de $10,40 \%$ na produtividade de grãos;

3) Coeficientes de correlação positivos foram estimados entre o parametro "Niveis Totais de Resistência" (NTR) e os componentes de produção avaliados: peso de grãos: 0,69

altura da inserçäo da folha bandeira: 0,72

altura de inserção da espiga superior: 0,45

prolificidade: 0,57

porcentagem de espigas sadias: 0,58

Com relação aos valores para altura, ocorre estimativa, em maior magnitude, para inserção da folha bandeira, devido à redução mais acentuada dos internódios superiores resultante da infecção; 
4) Infeccões severas ocasionam atraso na emissão do estilo estigma e consequente aumento na frequência de plantas sem espigas;

5) As características do método permitem sua aplicação para outras doenças do milho;

6) Solos pobres, mal equilibrados, que favorecem condiçöes de estresse, podem ser utilizados para a avaliação de doenças. 


\section{REFERENCIAS BIBLIOGRÁFICAS}

BALMER, E.; DE LEON, I. G. de; ZINSLY, J. R.; BORGES, R. T. P. B. Seleção na variedade Piranão SM XVIII visando resistência às doenças causadas pelo complexo virus-spiroplasma por Exserohilum turcicum. 1990. 18p. (Projeto Científico referente ao processo 93/0966-7 FAPESP).

BARBOSA, R. T. P.; PATERNIANI, E; ZINSSIY, J. R. Comportamento des populaçōes de milho (Zea mays L) Piranäo e Piranão do Inverno durante os periodos de inverno e de verão. In: Congresso Nacional de Milho e Sorgo, 18, Vitória, 1990. resumos. Vitória: EMCAPA, 1990 p. 56.

BEDENDO, I. V. Ambiente e doenca. In: BERGAMIN, A. F.; KIMATI, H. AMORIN L. (Ed.) Manual de Fitopatologia. 3 ed. São Paulo: Agronômica Ceres, 1995 cap. 18, p.331-341.

BHIRUD, K M; PITRE, H. N. Bioactivity of sistemic inseticides in corn: relationship to leafhopper vector control and corn stunt disease incidence. Journal of Economic Entomology, v. 65, n.4, p.1134-1140, 1972a.

BHIRUD, K. M. PITRE, H. N. Comparative susceptibility of three cicadellid vector of the corn stunt disease agent to carbofuran and disulfoton in 
greenhouse tests. Journal of Economic Entomology v $65, n .5$, p.1236$1238,1972 b$.

BLASINGAME, D. J; TOLER, R. W. Johnsongrass, a host of corn stunt. American Phytopathological Society: Abstracts for the 1973 Annual Meeting of Southern Division Ibid v $63, p .440,1973$.

BRADFUTE, O. E; TSAI, J. H. GORDON, D. T. Corn stunt spiroplasma and viroses associated with a maize disease opidemic in southern Florida Plant Disease v $65, n .10$, p $837-841,1981$.

BREWBAKER, J. L; KIM, S. K. ; LOGRONO, M. L. Resistance of tropical major virus and virus-like disease Maydica, v.36, n.3, p.257-265, 1991.

CHEN, T. A: LIAO, C. H. Corn stunt spiroplasma: isolation, cultivation and proof of pathogenicity. Science, v $188, n .4192$, p.1015-1017, 1975.

CHOUDHURY, M. M; ROSENKRAZ E. Differential transmission of Mississippi and Ohio corn stunt agents by Gramnella nigrifrons. Phytopathology $\vee 63$, ก. 1, p.127-133, 1973 .

COSTA, A. S.; KITAJIMA, E. W: ARRUDA, S. C. Moléstias de vírus e de micoplasma do milho em São Paulo. Revista Soc. Bras. Fitopatologia, v.4, p.39-41, 1971

DAVIS, R. E. Occurrence of a spiroplasma in corn stunt infected plants in Mexico. Plant Disease Reporter, y 57, n.4, p.333-337, 1973. 
DAVIS, R. E. Spiroplasma in corn stunt - infected individuals of the vector leafhopper Dalbulus maidis. Plant Disease Reporter, $y .58, n .12$, p.11091112,1974

DAVIS, R. E. Status of the identities of spiroplasmas infecting corn in the USA. Maize Virus Disease Newsletter, n. 1, p.34-38, 1984.

DAVIS, R. E; WORLEY, J. F. Spiroplasma: motile, helical microorganism associated with corn stunt disease. Phytopathology, v.63, n. $3,0.403-408$, 1973.

DE LEON, C. Development of disease resistant populations of maize for the tropics. Phytopathololy, $\vee .72$, , .4, p.452. 1982.

DE LEÓN, C. Molestias do milho: guia para identificação no campo. 2 ed. Campinas: Fundação Cergill, 1994. 119p.

EDEN-GREEN, S. J. Detection of corn stunt spiroplasma in vivo by ELISA using antisera to extracts from infected corn plants (Zea mays). Plant Pathology. v.31, n. $4,0.289-297,1982$.

DUARTE, A P.; ALLIPRANDINI, L. F; SAWAZAKI, E; KANTHCK, RA. D. Avaliaçao de cultivares de milho "safrinha"no vale Paranapanema. In: Congresso Nacional de Milho e Sorgo, 20., Goiânia, 1994. CentroOestecinturão de milho e sorgo no Brasil; resumos. Goiania: ABMSIEMGOPAIEMBRAPA, CNPMSIUFGIEMATER-GO, 1994 . p.91.

DUARTE, A P; ALIIPRANDIN!, L. F.; SAWAZAKI, E; KANTHCK, RA. D. Avaliacão de cultivares de milho no vale Paranapanema. In: Congresso 
Nacional de Milho e Sorgo, 20., Goiânia, 1994. Centro-Oeste:cinturão de milho e sorgo no Brasil; resumos. Goiania: ABMS/EMGOPAIEMBRAPA, CNPMSIUFGIEMATER-GO, 1994, p.93.

FERNANDES, F. T; BAIMER, E. Situação das doenças de milho no Brasil. Informe Agropecuário, v.14, n. 165, p.37-40, 1990.

GAMEZ, $R$. Transmission of rayado fino virus of maize (Zea mays) by Dalbulus maidis. Annals of Applied Biology, v.73, n. 3, p. 285-292, 1973.

GAMEZ, R. Rayado fino virus disease of maize in the American tropics. Tropical Post Management Formely = PANS, v.26, n.1, p.26-33, 1980.

GAMEZ, R.; KITA.IMMA, E. W: LIN, M. T. The geographical distribution of maize rayado fino virus. Plant Disease Reporter, v.63, n.10, p. 830-833, 1979.

GODOI, R. E. Z de. Avaliação de progênies de milho (Zea mays) utilizando testemunha intercalar. Piracicaba,1994. 65p. Dissertacão (M.S.) - Escola Superior de Agricultura "Luiz de Queiroz", Universidade de São Paulo.

GOMES, F. P. Curso de estatistica experimental. São Paulo: Nobel, 1990. cap. 3, p.18-41: Os testes ou provas de significancie.

GORDON, D. T; NAULT, L. R. Involvement of maize chlorotic dwarf virus and other agents in stunting diseasesos Zea mays in the Unites States. Phytopathology, v.67, n.1, p.27-36, 1977.

GROGAN: C. O: ROSENKRAZ, E. E. Genetics of host reaction to corn stunt virus. Crop Science, v. 8, p.251-254. 1968. 
GRANADOS, R. R.; WHITCOMB, R. F. Transmission of corn stunt mycoplasma by the leafhooper Baldulus tripsaci. Phytopathology, v.61, n.2, 0.240-241, 1971.

HARRISON, N. A; RICHARDSON, P. A; TSAI, J. H; EBBERT, M. A; KRAMER, J. B. PCR assay for detection of the phytoplasma associated with maize bushy stunt maize. Plant Disease, v $80, n .3,0.263-269,1996$.

KITAJIMA, E. W; COSTA, A. S. Electron microscopy of mycoplasme - type micro-organisms in maize tissues attacked by stunt and in organs of the leafhopper vector. Bragantia, v.31, n.6, p.75-82, 1972.

KITAJIMA, E. W; COSTA, A. S. Diseases of maize caused by viruses and mycoplasmalike organisms in Brazil. In: International Maize Virus Disease Collocuiun and Workshop, 2-6., Wooster, 1983. Wooster, Proceedings. Ohio Agriculture and Development Center, 1983. 100-102.

KITAJIMA, E. W; GAMEZ, R. Histological observations on maize leaf tissues infected with rayado fino virus. Turrialba, v. $27, n .1$, p.71-74, 1977.

KOGEL, R; HAMMOND, R. W; RAMIREZ, P. Incidence and geographic distribution of maize rayado fino virus (MRFV) in Latin America. Plant Disease, v. 80, n.6. p.679-683, 1996.

LASTRA, R.; CARBALLO, O. Maize virus disease problems in Venezuela In: International Maize Virus Disease Colloquiun and Workshop, 2-6., Wooster, Proceedings. Ohio Agriculture and Development Center, 1983. p.83-86. 
LEGRAND, A.1.; POWER, A. G. Inoculation and acquisition of maize bushy stunt mycoplasma by its leaf-hopper vector Dalbulus maidis. Annals of Applied Biology, v 125, n.1, p.115-122, 1994

LONNQUIST, J. H. Mass selection for prolicacy in maize. Der Zücter, v 37 , p.185-188, 1967.

MAROUEZ SANCHEZ, F. The genetic improvement of resistance to the maize disease stunt and downy mildew in Nicaragua. Project CP-UACH-UNAN. Revista Chapingo, v.7, n. 35-36, p. 26-27, 1982.

MIRANDA, L. T: MIRANDA, L. E. C. de: SAWAZAKI, E; SCHMIDT, N. C Genetics of horizontal resitance to pests by glucosides and super-genes. Maize Genetics Cooperation News Letter, y.57, p.20-24, 1983.

NAULT, L. R. Maize bushy stunt and corn stunt: a comparison of disease symptoms, pathogen host ranges, and vectors. Phytopathology, v.70, n.7, p.659-662, 1980.

NAULT, L. R. Dalbulus leafhopper vectors of maize pathogens. Maize Virus Diseases Newsletter $n .1$, p.61-63. 1984 a.

NAULT, L. R. Corn leafhopper: the making of a insect pest. Ohio Report, v.69: n. $5,0.77-78,1984 b$

NAULT, L. R.; BRADFUTE, O. E. Corn stunt: involvement of a complex of leathopper - borne pathogens. In: MARAMOROSCH, K; HARRIS, K. (Ed) Leafhopper vectors and plant disease agents. London, Academy Press, 1979. p.561-586. 
NAULT, L. R.; DeLONG, D. M. Evidence for co-evolution of leafhoppers in the genus Dalbulus (Cicadeliidae: Homoptera) with maize and its ancestors. Annals of the entomological society of America, $v .73, n .4, p .349-353$, 1980.

NAULT, L. R. FINDIEY, W. R. Zea diploperennis - primitive relative offers new traits for com improvement. Ohio Report on Research and Developement in Agriculture, Home Economics, and Natural Resources, v.66, n.6, p.90-92, 1981

NEISON, L. R. SCOTT, G. E. Diallol analysis of resistance of corn (Zea mays) to corn stunt Crop Science, v.13, n.2, p.162-164. 1973.

NOME, S. F: LENARDON, S. L: RAJU, B. C: LAGUNA, I. G: LOWE, S. K; DOCAMPO, D. Association of reovirus-like particles with "enfermedad de Rio IV" of maize in Argentina. Phytopathologische Zeitschrift, v.101, n.1, p. $7-15,1981$

OVERMAN, M. A.; KO, N.J.; TSAI, J. H. Identification of viruses and mycoplasmas in maize by use of light microscopy. Plant Disease, v.76, n.3, p. 318-322, 1992.

PANIAGUA, R.; GAMEZ, R. Rayado fino virus of maize: addtional studies on the relation between the virus and its insect vector. Turrialba, v.26, n.1, p.39-43, 1976. 
RAJU, B. C.; NYLUND, G. Enzyme - linked immunosorbent assay for the detection of com stunt spiroplasma in plant and insect tissue. Current Microbiology, v. 5, n.2, p. 101-104, 1981.

RENFRO, B. L. Maize production and improvement in the tropics and subtropics In: WILLIAMS, L. E; GORDON, D. T; NAULT, L. R. (Ed). International maize virus disease colloquium and workshop proceedings. 1977, p.9.

SCOTT, G. E: ROSENKRAZ, E. E. Independent inheritence of resistance to corn stunt and maize dwarf mosaic in corn Crop Science, v.14, n.1, p.104$106,1974 a$.

SCOTT, G. E. ROSENKRAZ, E. E. Effectiveness of recurrent selection for corn stunt resistance in maize variety. Crop Science, $y, 14, n .5,0.758-760$. $1974 b$.

SCOTT, G. E. ROSENKRAZ, E. E. Frequency of progenies resistant to corn stunt and maize dwarf mosaic in maize populations. Crop Science, v.15, ก.2, p.233-235. 1975

SCOTT, G. E.; ROSENKRAZ, E. E. Location of genes conditioning resistance to the corn stunt disease complex in maize. Crop Science, v.17, n.6, p.923925. 1977.

SCOTT, G. E.; ROSENKRAZ, E. E; NEISON, L. R. Yield loss of corn due to corn stunt disease complex. Agronomy Joumal, v.69, n.1, p.92-94, 1977. 
WAOULL, J. M. CRUZ, I. Impacto do tratamento de sementes de milho na infestaçăo por Dalbulus maidis e Spodoptera frugiperda. In: Congresso Nacional de Milho e Sorgo, 20, Goiania, 1994. Centro-Oestecinturão de milho e sorgo no Brasil; resumos. Goiannia: ABMSIEMGOPA/EMBRAPA, CNPMSUIFGIEMATER-GO, 1994, p.153.

WOLANSKI, B. S: MARAMOROSCH, K. Rayado fino virus and corn stunt spiroplasma: phloem restriction and transmission by Dalbulus elimatus and Dalbulus maidis. Fitopatologia Brasileira, v. 4, n.1, p. 47-54, 1979.

ZUBFR, MS. Relative efficiency of incomplete block desing using corn uniformity trial data. Joumal American Society Agronomy, v $34,0.30-47$; 1942 